OPEN ACCESS

Edited by:

Rui Rosa,

University of Lisbon, Portugal

Reviewed by:

Ana Colaço,

Marine Research Institute (IMAR),

Portugal

Clara Rodrigues,

University of Aveiro, Portugal

${ }^{*}$ Correspondence:

Luigia Donnarumma

luigia.donnarumma@uniparthenope.it

Specialty section:

This article was submitted to Global Change and the Future Ocean,

a section of the journal

Frontiers in Marine Science

Received: 23 April 2019

Accepted: 24 October 2019

Published: 08 November 2019

Citation:

Donnarumma L, Appolloni L, Chianese E, Bruno R, Baldrighi E, Guglielmo R, Russo GF, Zeppilli D and Sandulli R (2019) Environmental and Benthic Community Patterns of the Shallow Hydrothermal Area of Secca Delle Fumose (Baia, Naples,

Italy). Front. Mar. Sci. 6:685 doi: 10.3389/fmars.2019.00685

\section{Environmental and Benthic Community Patterns of the Shallow Hydrothermal Area of Secca Delle Fumose (Baia, Naples, Italy)}

\author{
Luigia Donnarumma ${ }^{1,2 *}$, Luca Appolloni1,2, Elena Chianese ${ }^{1}$, Renato Bruno ${ }^{3}$, \\ Elisa Baldrighi ${ }^{4}$, Rosanna Guglielmo5, Giovanni F. Russo ${ }^{1,2}$, Daniela Zeppilli ${ }^{4}$ and \\ Roberto Sandulli1,2
}

\footnotetext{
1 Laboratory of Marine Ecology, Department of Science and Technology, University of Naples "Parthenope", Naples, Italy, ${ }^{2}$ National Interuniversity Consortium for Marine Sciences, Rome, Italy, ${ }^{3}$ EEP/SPICl Group/UMR 8198, Department of Sciences et Technologies, University of Lille, Villeneuve-d'Ascq, France, ${ }^{4}$ IFREMER, Centre Brest, REM/EEP/LEP, Plouzané, France, ${ }^{5}$ Integrative Marine Ecology Department, Stazione Zoologica Anton Dohrn, Naples, Italy
}

The occurrence of hydrothermal vent ecosystems at Secca delle Fumose, Pozzuoli Bay (Gulf of Naples), represented an opportunity to study the benthic assemblages under the thermal stress of hydrothermal emissions in a very shallow environment (914 m water depth). In autumn 2016, the macrobenthic community was sampled by scuba divers at four sites located in the Baia Underwater Archeological Park. Two sites were characterized by vent emissions (one with white bacterial mat scattered on the bottom and one with a yellow substrate around a geyser opening) and two at about 100 m away, used as control. Sediment and interstitial water environmental variables were measured to determine their influence on the structure of macrobenthic assemblages. A total of 1,954 macrofaunal individuals was found, characterized by great differences in abundance and species richness among sites. This pattern was correlated to the dominance of a particular set of variables that drastically change in a very small spatial scale, from one site to another. The control sites, characterized by the highest percentage of gravel in the sediments (19.67 $\pm 2.6 \%$ ) and normal level of major ions such as $\mathrm{Ca}^{2+}, \mathrm{K}^{+}$, and $\mathrm{Mg}^{2+}$ in the interstitial waters, showed the highest values of sinecological indices. The "white" hydrothermal site exhibited the lowest species richness, abundance and species diversity, influenced by low $\mathrm{pH}$ values $(\sim 7.6)$, high temperatures $\left(\sim 37.53^{\circ} \mathrm{C}\right)$ and by the highest total organic carbon content (TOC 34.78\%) in the sediment. The "yellow" hydrothermal site, with sediment TOC equal to $30.03 \%$ and interstitial sulfide ions measuring 130.58 ppm, showed higher values of sinecological indices than those recorded at the "white" site. Therefore, taxonomic analysis revealed a high turnover between control and vents sites. This highlights the preference for hydrothermal vents by a few resistant species, such as the gastropod Tritia cuvierii and the polychaete Capitella capitata, confirming the role of the latter species as opportunistic in extreme environments like Secca delle Fumose.

Keywords: shallow hydrothermal vents, interstitial water, sediments, macrofauna, benthos, extreme habitats, Mediterranean Sea 


\section{INTRODUCTION}

The relationship between environmental factors and benthic communities is of primary importance in determining the structure of biocenoses and their functioning (e.g., Feder et al., 1994; Ellingsen, 2002; Lloret and Marín, 2009; Arribas et al., 2014). A huge variety of marine species and bioconstructions is widely distributed along the bathymetrical gradient, from very shallow to deep-water. Among extreme marine systems, hydrothermal vents have wide global distribution, occurring in all oceanic bottoms, at different latitudes and depths and harboring rich and peculiar biological communities (Parson et al., 1995; Dando et al., 2000). Several studies revealed that the occurrence of benthic organisms in the hydrothermal systems is strongly related to the volcanic fluids that outflow from the bottom, characterized by high concentrations of iron, zinc sulfides and gases, such as $\mathrm{CH}_{4}, \mathrm{H}_{2} \mathrm{~S}, \mathrm{H}_{2}$, and $\mathrm{CO}_{2}$ (e.g., Van Dover and Fry, 1989; Micheli et al., 2002; Hall-Spencer et al., 2008; Martin et al., 2008; Yao et al., 2010). A great biological difference occurs between deep and shallow vents. The former are mainly characterized by chemolithotrophic bacteria using $\mathrm{H}_{2} \mathrm{~S}$ as energy source, representing the basis for a complex heterotrophic ecosystem, while the latter are composed both by chemolithotrophic bacteria and by communities energetically driven by photosynthetic organisms, such as diatoms and algal-bacterial mats absent in deep-sea vents communities (Vismann, 1991; Lutz and Kennish, 1993; Tarasov et al., 2005; Raghukumar et al., 2008).

In the Mediterranean Sea, very shallow hydrothermal vents were reported for the Tyrrhenian and Aegean Sea, ranging from few meters to about $30 \mathrm{~m}$ depth (Dando et al., 1999). They are related to tectonically active coastal zones, where the volcanic fluids are characterized by high temperatures and mainly composed by sulfide and/or $\mathrm{CO}_{2}$ (Dando et al., 2000). Even though shallow benthic communities include tolerant species to natural or anthropogenic stressors, many studies have suggested that the increasing temperature and sulfides negatively affect a wide variety of benthic assemblages, reducing the water oxygen concentration and producing toxicity to the majority of aerobic species (Caldwell, 1975; Wang and Chapman, 1999; Vaquer-Sunyer and Duarte, 2010, 2011). Similarly, natural $\mathrm{CO}_{2}$ emissions in seawater produce a change in carbonate chemistry, resulting in a local seawater acidification, which, in turn, impacts on

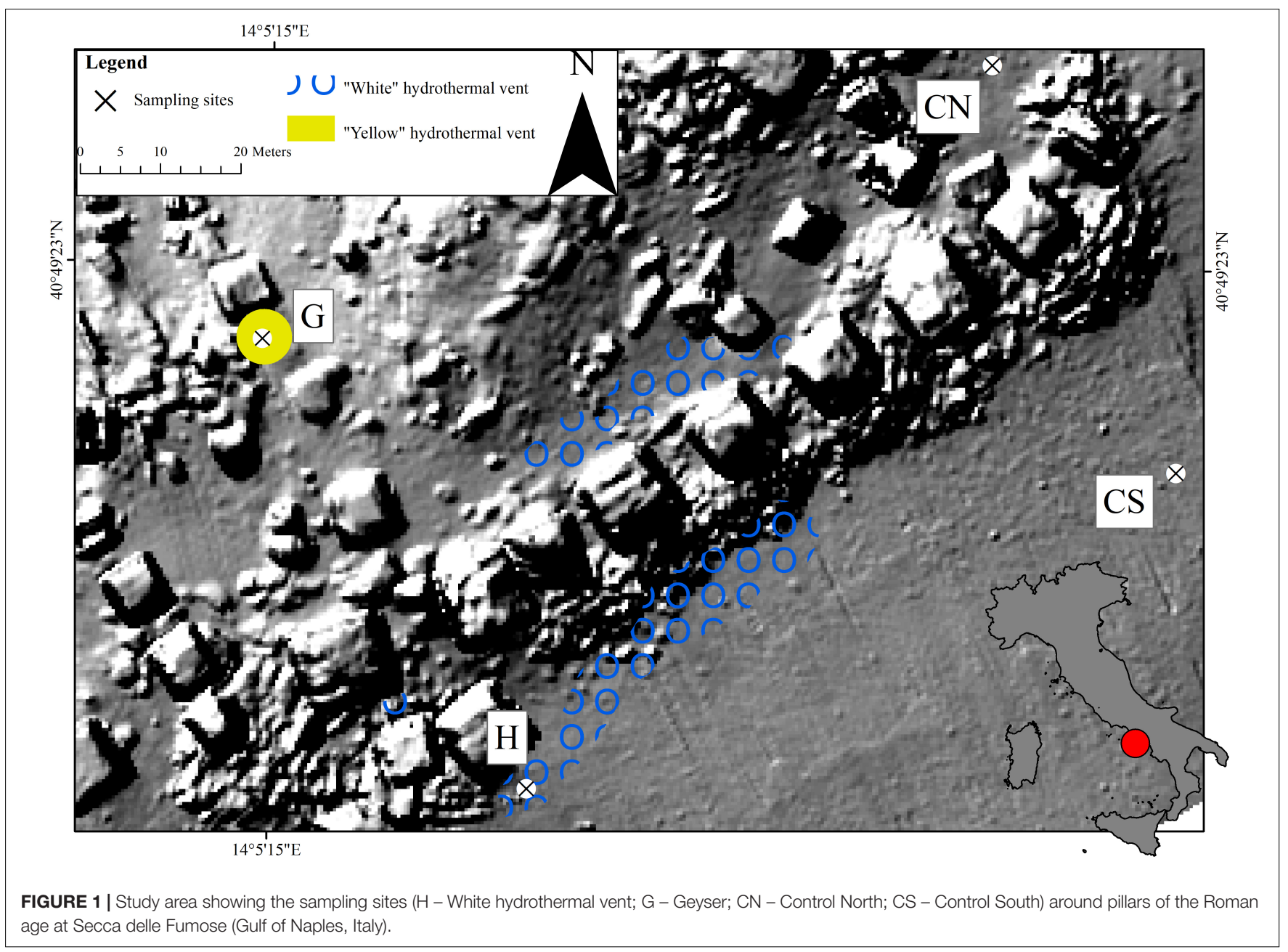


calcification and growth processes of many planktic and benthic species (Fabry et al., 2008; Doney et al., 2009; Wicks and Roberts, 2012).

Volcanic emissions, rich in $\mathrm{CO}_{2}$, were previously reported by Hall-Spencer et al. (2008) for the cold vents of Ischia Island, in the Gulf of Naples (Italy). Here, sulfides are absent while the high percentage of $\mathrm{CO}_{2}(\sim 90-95 \%)$ considerably reduces the seawater $\mathrm{pH}$ which negatively affects calcifying organisms (Cigliano et al., 2010; Donnarumma et al., 2014; Lucey et al., 2016; Teixidó et al., 2018).

A few kilometers away from Ischia Island, in the Campi Flegrei caldera, Di Napoli et al. (2016) reported a remarkable variation in seawater $\mathrm{pH}(\sim 7.3-8.3)$ due to the gas-rich hydrothermal fluids occurring in a shallow submarine relief, namely Secca delle Fumose. This area was only recently investigated from a geological (e.g., Tedesco et al., 1990; Passaro et al., 2013) and microbiological (Maugeri et al., 2010), point of view. Highresolution morpho-bathymetric data and archeological surveys indicate that the relief is largely anthropogenic, consisting of a dense aggregation of pillars of the Roman age (first century $\mathrm{BC}$ ), with a perimeter of $9 \mathrm{~m} \times 9 \mathrm{~m}$ and a height of $7 \mathrm{~m}$, mostly standing on a seafloor at $12 \mathrm{~m}$ depth where hydrothermal vents occur. Since there is a lack of information concerning the other biological and ecological components, the aims of this paper are: (i) to evaluate the spatial variation of macrobenthic community at the Secca delle Fumose, (ii) to assess the most important abiotic parameters affecting softbottom assemblage structure and (iii) to estimate the taxonomic diversity among hydrothermal vents and non-vent sites. To our knowledge, this study represents the first investigation of macrobenthic assemblages inhabiting the shallow hydrothermal systems of Campi Flegrei.

\section{MATERIALS AND METHODS}

\section{Site Description}

"Secca delle Fumose" (SdF) belongs to the largest degassing structure offshore of the Campi Flegrei caldera. With an extension of approximately $0.14 \mathrm{~km}^{2}$, is located about $800 \mathrm{~m}$ off the coastline in the north-western part of Pozzuoli Bay (Gulf of Naples, Italy) $\left(40^{\circ} 49^{\prime} 23^{\prime \prime} \mathrm{N} 14^{\circ} 05^{\prime} 15^{\prime \prime} \mathrm{E}\right)$ (Tedesco et al., 1990; Passaro et al., 2013; Di Napoli et al., 2016). In this area, four sampling sites were selected (Figure 1), two control sites $(\mathrm{CN}$; $\mathrm{CS})$ and two in proximity of very different vents: a first characterized by white bacterial mats $(\mathrm{H})$ and a second by yellow substrate around a solitary geyser opening $(G)$. The control sites were distant about $65 \mathrm{~m}$ each other and $100 \mathrm{~m}$ away, in the hydrothermal area, the other two sites were sampled at the same distance from each other.

\section{Sampling Collection and Analytical Procedures}

In each site (H, G, CN, and CS) in November 2016, environmental parameters were measured (temperature and $\mathrm{pH}$ ) and samples for interstitial water chemistry, grain size, total organic carbon (TOC) and sediment macrofauna were collected in triplicate.

Sediment temperature was measured in situ by means of an underwater thermometer. Water samples at water/sediment interface were collected for $\mathrm{pH}$ evaluation ( $\mathrm{pH} / \mathrm{ORP}$ Meter, HI98171, and probe HI 1230, Hanna instr.). Interstitial water $(20 \mathrm{ml})$ for ions and metals determination was sampled using syringes and kept frozen until analyses; sediment samples were collected for the grain size and TOC analysis, by means

TABLE 1 | Environmental condition of the study area. Data were expressed as percentages or averaged ( \pm S.D.) among three replicates at each site (H; G; CN; CS).

\begin{tabular}{|c|c|c|c|c|c|}
\hline VARIABLES & & $\mathbf{H}$ & $\mathbf{G}$ & $\mathrm{CN}$ & CS \\
\hline \multicolumn{6}{|c|}{ Sediment variables } \\
\hline Temperatures $\left({ }^{\circ} \mathrm{C}\right)$ & & $37.53 \pm 2.28$ & $29.1 \pm 2.81$ & 21.8 & 21.8 \\
\hline $\mathrm{pH}$ & & $7.56 \pm 0.05$ & 8 & 8.1 & 8.1 \\
\hline TOC (\%) & & 34.78 & 30.03 & 17.05 & 18.14 \\
\hline Gravel (\%) & & 7.41 & 13.96 & 17.84 & 21.52 \\
\hline Sand (\%) & & 90.12 & 83.40 & 79.60 & 76.67 \\
\hline Mud (\%) & & 2.47 & 2.64 & 2.57 & 1.81 \\
\hline \multicolumn{6}{|c|}{ Interstitial water variables } \\
\hline \multirow[t]{8}{*}{ Ions (ppm) } & $\mathrm{Na}^{+}$ & $8668.260 \pm 4.5$ & $9973.210 \pm 10.5$ & $10776.925 \pm 12.5$ & $11120.825 \pm 18.7$ \\
\hline & $\mathrm{Cl}^{-}$ & $19512.965 \pm 20.5$ & $23726.385 \pm 15.7$ & $26039.500 \pm 17.5$ & $25976.560 \pm 18.6$ \\
\hline & $\mathrm{K}^{+}$ & $317.855 \pm 7.6$ & $426.340 \pm 10.2$ & $407.405 \pm 8.5$ & $399.125 \pm 6.2$ \\
\hline & $\mathrm{Mg}^{2+}$ & $805.000 \pm 7.3$ & $954.705 \pm 3.8$ & $1219.475 \pm 8.8$ & $1179.500 \pm 5.2$ \\
\hline & $\mathrm{Ca}^{2+}$ & $327.500 \pm 8.3$ & $472.200 \pm 9.5$ & $503.290 \pm 9.2$ & $385.725 \pm 7.3$ \\
\hline & $\mathrm{NO}_{3}^{-}$ & $28.77 \pm 0.06$ & $25.50 \pm 0.06$ & $26.07 \pm 0.03$ & $25.68 \pm 0.32$ \\
\hline & $\mathrm{SO}_{4}{ }^{2-}$ & $3152.300 \pm 3.6$ & $2658.500 \pm 6.5$ & $3369.880 \pm 3.1$ & $3888.500 \pm 5.9$ \\
\hline & $S^{2-}$ & $<$ lod & 130.58 & $<$ lod & $<$ lod \\
\hline \multirow[t]{4}{*}{ Metals (ppb) } & $\mathrm{Zn}$ & $33.66 \pm 0.51$ & $34.56 \pm 3.86$ & $39.09 \pm 0.50$ & $33.55 \pm 0.50$ \\
\hline & $\mathrm{Pb}$ & $62.02 \pm 0.16$ & $31.29 \pm 0.52$ & $18.31 \pm 0.60$ & $60.02 \pm 0.71$ \\
\hline & $\mathrm{Cd}$ & $4.42 \pm 0.19$ & $<$ lod & $<$ lod & $4.42 \pm 0.18$ \\
\hline & $\mathrm{Cu}$ & $<$ lod & $8.88 \pm 0.21$ & $5.25 \pm 0.21$ & $<$ lod \\
\hline
\end{tabular}

lod (limit of detection): 2 ppm for $\mathrm{S}^{2-} ; 0.8 \mathrm{ppb}$ for $\mathrm{Cd}$; 0.1 ppb for $\mathrm{Cu}$. 
of a cylindrical corer $(5.5 \mathrm{~cm}$ diameter $)$ pushed $10 \mathrm{~cm}$ into the sediment.

In the laboratory, interstitial water was filtered with cellulose filters $(0.20 \mu \mathrm{m})$ and treated with $\mathrm{H}_{2} \mathrm{O}_{2}(100 \mu \mathrm{l}$ in $10 \mathrm{ml}$ of sample) for the digestion of organic content; samples were then fractioned in two aliquots for ions and metals determination.

For the analysis of major ions concentration, interstitial water samples were analyzed through ICS1100 ion chromatographic system, equipped with a double column system for simultaneous analyses of both anions and cations (Chianese et al., 2019); anions were detected with an AS22 column working with a cell volume of $100 \mu \mathrm{l}$ and a solution $3.5 \mathrm{mM}$ of sodium carbonate/bicarbonate as eluent, while cations were determined with a CS12A column working with a cell volume of $25 \mu \mathrm{l}$ and $20 \mathrm{mM}$ methanesulfonic acid solution as eluent. For both anions and cations, calibration curves were calculated using certified multistandard solutions; anions and cations detectable with this method are respectively: $\mathrm{Cl}^{-}, \mathrm{F}^{-}, \mathrm{Br}^{-}, \mathrm{NO}_{2}^{-}, \mathrm{NO}_{3}^{-}, \mathrm{PO}_{4}^{3-}, \mathrm{SO}_{4}^{2-}$ (as inorganic species), $\mathrm{HCOO}^{-}, \mathrm{CH}_{3} \mathrm{COO}^{-}, \mathrm{C}_{2} \mathrm{O}_{4}^{-2}$ (as organic species) and $\mathrm{Li}^{+}, \mathrm{Na}^{+}, \mathrm{K}^{+}, \mathrm{NH}_{4}^{+}, \mathrm{Ca}^{2+}$, and $\mathrm{Mg}^{2+}$. In addition the $\mathrm{S}^{2-}$ ion was estimated using a chromatographic method, converting it in sulfate ion after oxidation with $\mathrm{H}_{2} \mathrm{O}_{2}$. Heavy metals $(\mathrm{Pb}, \mathrm{Cd}, \mathrm{Cu}$, and $\mathrm{Zn})$ were estimated by means of a polarographic method, with a Metrohm 797 VA Computrace; this system uses a multimode working Mercury electrode and an $\mathrm{Ag} / \mathrm{AgCl}$ electrode as reference. Using this method, metals that are soluble in mercury such as zinc, cadmium, lead, and copper are simultaneously determinable (Chianese et al., 2019). Also in this case, calibration curves were calculated using certified multistandard solutions.

For the grain size analysis (Eleftheriou and McIntyre, 2008), sediment was sieved over a series of 11 sieves with mesh size ranging from $1 \mathrm{~cm}$ to $63 \mu \mathrm{m}$. Fractions were dried in oven at $60^{\circ} \mathrm{C}$ for $48 \mathrm{~h}$ and weighed; data were expressed as percentages of the total sediment dry weight, differencing it in three size classes: gravel $(>2 \mathrm{~mm})$, sand $(2 \mathrm{~mm}<\varnothing>0.063 \mathrm{~mm})$, and mud $(<0.063 \mathrm{~mm})$. TOC was determined according to Schumacher (2002) and expressed as\% of sediment.

As for macrofauna community, samples were collected at each site by scuba-diving operators using an air-lift pump equipped with a $0.5 \mathrm{~mm}$ nylon mesh size bag (Benson, 1989; Chemello and Russo, 1997) within a $50 \mathrm{~cm} \times 50 \mathrm{~cm}$ frame, reaching a depth of $10 \mathrm{~cm}$ in the sediment. In the laboratory, the samples were fixed in $70 \%$ ethanol and macrofauna was sorted and analyzed under a stereomicroscope. Macrofauna organisms were analyzed up to the lowest taxonomic level, when possible, and their identification was cross-checked with the World Register of Marine Species (WoRMS Editorial Board, 2018).

\section{Data Analysis}

Multivariate ordination by principal component analysis (PCA) was performed on normalized environmental variables in order to determine their distribution patterns among the four sampling sites.

Sinecological indices, such as number of individuals (N) per $25 \mathrm{dm}^{3}$, species richness (SR), Shannon-Weaver diversity $\left(\mathrm{H}^{\prime}\right.$ :

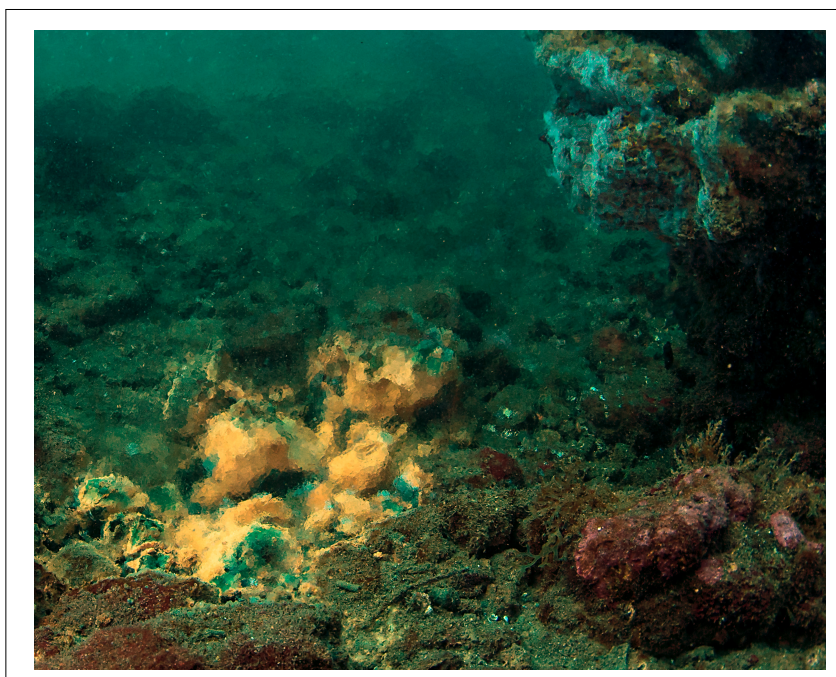

FIGURE 2 | The hydrothermal geyser with surrounding rocky substrate covered by yellow sulfur deposits.

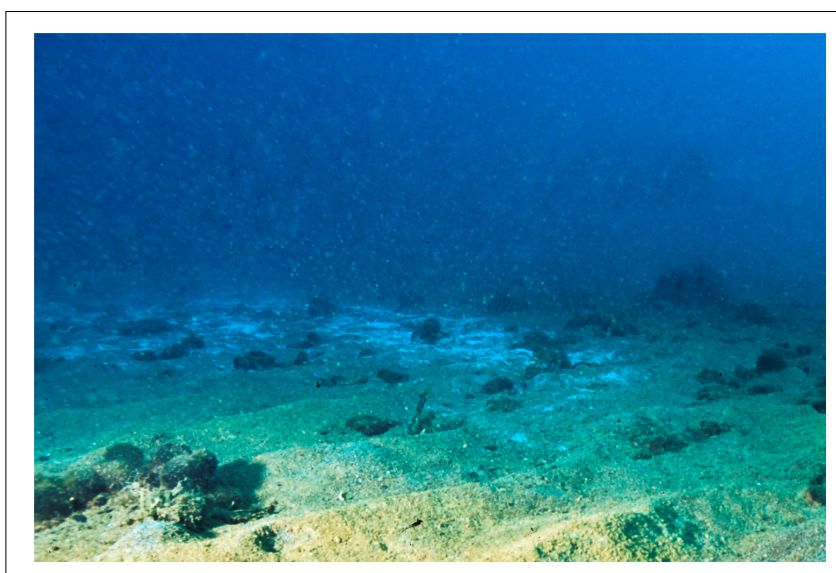

FIGURE 3 | Hydrothermal site with soft bottom covered by a white microbial mat.

$\left.\log _{2}\right)$ and Pielou's evenness (J) were calculated based on three replicate samples for each site. The quantitative (DI, percentage of individuals of a given species upon total individuals collected in the sample) and qualitative dominances (DQ, percentage of species of a given taxon upon the total of species collected in the sample) were also calculated. Differences of sinecological variable among sites were detected by permutational analysis of variance (PERMANOVA; Anderson, 2001a), based on Euclidean distance (Terlizzi et al., 2007). A one-way experimental design with $n=3$ was involved with the fixed factor Site (four levels). PERMANOVA analysis, based on Bray-Curtis similarity, was also performed in order to assess differences in the structure of community assemblages among sites. 4999 permutations were always applied (Anderson, 2001b) and a PERMANOVA pairwise $t$-test was used in order to evaluate differences between pairs of sites. Prior to analysis, data were $\log (\mathrm{x}+1)$ transformed (Clarke and Warwick, 2001) in order to normalize the data. 


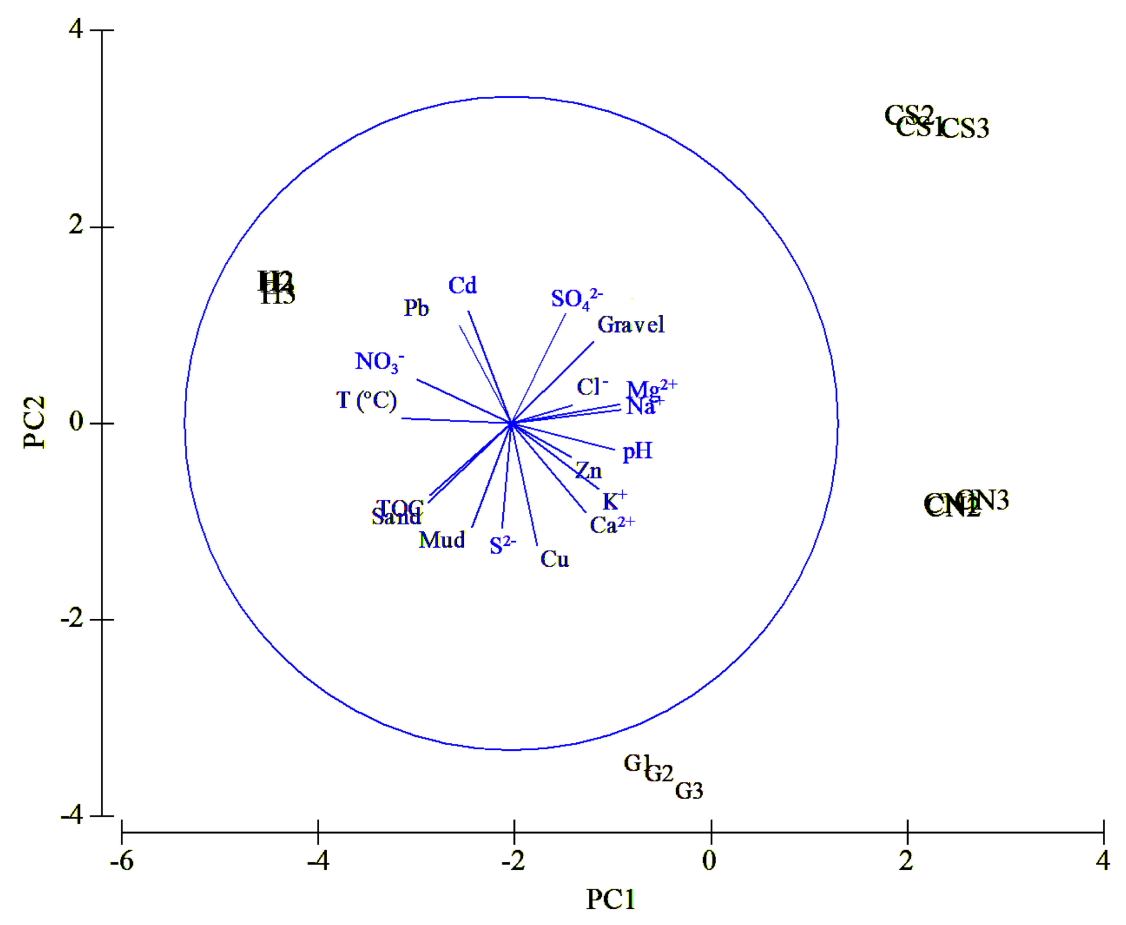

FIGURE 4 | Ordination of environmental variables at the four sites of the Secca delle Fumose using PCA.

To examine the structural variation of benthic communities among sites, canonical analysis of principal coordinates (CAP; Anderson and Willis, 2003) was used and similarity percentage (SIMPER) was calculated among the replicates for each site and, then, it was applied to identify those species that contributed more to the similarity among sites. Only species that cumulatively contributed to $50 \%$ to similarity were considered.

Relationships between macrobenthic community composition and environmental variables were tested by distance-based linear modeling analysis routine (distLM, Anderson, 2004). The aim was to identify which variables were mostly related with assemblages and to better explain the biological pattern among sites. Then, distance based redundancy analysis (dbRDA, Legendre and Anderson, 1999) was used to visualize the influence of variables identified by distLM. For distLM analysis, interstitial water variables, expressed in $p p m$ and $p p b$, were $\log _{10}$ transformed to better compare different scales (Underwood, 1997). All multivariate analyses were undertaken using the PRIMER-PERMANOVA + v.6 software package (Anderson et al., 2008).

\section{RESULTS}

\section{Environmental Variables}

Environmental characteristics of SdF are summarized in Table 1. A solitary hydrothermal vent (geyser) at $G$ site is present at $10 \mathrm{~m}$ depth. The vent opening was about $10 \mathrm{~cm}$ in diameter; the hydrothermal fluid temperature reaches $\sim 80^{\circ} \mathrm{C}$ at the outlet, while a lower temperature $\left(29.1 \pm 2.81^{\circ} \mathrm{C}\right)$ and a moderate $\mathrm{pH}$ value (8) occurred in the sediment at a distance of $20 \mathrm{~cm}$ from the vent center. Rocky substrate surrounding the geyser was covered by yellow sulfur deposits (Figure 2), while soft substrate among the rocks presented a TOC content of $30.03 \%$. Interstitial water had a sulfur ion $\mathrm{S}^{2-}$ concentration of $130.58 \mathrm{ppm}$. Here, the most abundant ions were sulfate $\mathrm{SO}_{4}^{-2}$, with a concentration of $2658.500 \pm 6.5 \mathrm{ppm}$, and $\mathrm{Mg}$, with a concentration of $954.705 \pm 3.8 \mathrm{ppm}$, furthermore, relevant values of metals such as $\mathrm{Zn}(34.56 \pm 3.86 p p b)$ and $\mathrm{Pb}(31.29 \pm 0.52 p p b)$ were detected. About $1 \mathrm{~m}$ from the vent, where macrofauna was collected, the sediment was composed by sand $(83.40 \%)$, gravel $(13.96 \%)$, and mud (2.64\%).

The $\mathrm{H}$ site was approximately $65 \mathrm{~m}$ from the $\mathrm{G}$ site, at a depth of $14 \mathrm{~m}$. The sediment temperature was about $37.53 \pm 2.28^{\circ} \mathrm{C}$ and the $\mathrm{pH}$ value $7.56 \pm 0.05$, indicating an acidified condition, where some gas bubbling occurred. This site was characterized by a soft bottom covered by a white microbial mat (Figure 3), with a TOC content of $34.78 \%$. Sediment was mainly composed by sand $(90.12 \%)$, gravel $(7.41 \%)$ and mud $(2.47 \%)$, while interstitial water showed the highest mean value of $\mathrm{NO}_{3}^{-}(28.77 \pm 0.06 \mathrm{ppm})$ respect to the other sites, and a high mean value of $\mathrm{Pb}$ $(62.02 \pm 0.16 p p b)$ among metals.

The two control sampling sites (CN and CS) were located respectively to the north and south of Roman pillars and $100 \mathrm{~m}$ from $\mathrm{G}$ and $\mathrm{H}$ at a depth of 9.8 and $12.1 \mathrm{~m}$ respectively. In these sites, the gas emissions and the white microbial mat were absent, while the sediment temperature of $21.8^{\circ} \mathrm{C}$ was comparable to that of sea water column; the $\mathrm{pH}$ values (average 8.1) were within the range of normal conditions. The content of the TOC in the sediment varied from 17.05 to $18.14 \%$. The 
sediment grain size was characterized by a high percentage of sand (CN 79.60\%; CS 76.67\%) and a lower content of gravel (CN 17.84\%; CS 21.52\%) and mud (CN 2.57\%; CS 1.81\%). High concentrations of heavy metals occurred in the interstitial water in both sites: the $\mathrm{CN}$ site was mainly characterized by a $\mathrm{Zn}$ content of $39.09 \pm 0.50 p p b$, while $\mathrm{CS}$ by $\mathrm{Pb}$ concentrations of $60.02 \pm 0.71 p p b$. This latter site presented also the highest mean value of $\mathrm{SO}_{4}^{2-}(3888.500 \pm 5.9 \mathrm{ppm})$.

The sediment quality characteristics from sampling sites were shown by multivariate PCA (Figure 4). In particular, PC1 accounted for $47.5 \%$ of variation among sites, and PC1 and PC2 together accounted for $84.5 \%$ (Table 2). Along the PC1 axis, hydrothermal vent sites $(\mathrm{H}$ and $\mathrm{G})$ were separated from the control sites (CN and $\mathrm{CS}$ ), according to temperature and ion $\mathrm{NO}_{3}^{-}$, that were high at the active sites; on the contrary other ions (e.g., $\mathrm{Mg}^{2+} ; \mathrm{Na}^{+}$) and $\mathrm{pH}$, were high at control sites (Figure 4 $\mathrm{PC} 1)$. Along the PC2 axis, the graph showed a clear separation between southern ( $\mathrm{H}$ and $\mathrm{CS}$ ) and northern ( $\mathrm{G}$ and $\mathrm{CN}$ ) sites; the former sites were displaced on the graph according to heavy metals content such as $\mathrm{Cd}$ and $\mathrm{Pb}$ and the $\mathrm{SO}_{4}^{2-}$ ion; the latter sites according to $\mathrm{Cu}, \mathrm{S}^{2-}$ ion and\% of mud (Figure 4 - PC2).

\section{Macrofauna Diversity and Community Structure}

A total number of 1,954 individuals, belonging to 164 taxa grouped in eight macrobenthic groups, were classified to

TABLE 2 | Principal component loadings for hydrothermal and control sites from PCA of environmental data from four sites sampled at the Secca delle Fumose hydrothermal zone.

\begin{tabular}{|c|c|c|c|}
\hline PC & Eigenvalues & $\%$ Variation & Cum.\%Variation \\
\hline 1 & 8.54 & 47.5 & 47.5 \\
\hline 2 & 6.66 & 37 & 84.5 \\
\hline \multicolumn{2}{|c|}{ Environmental variables } & PC1 & PC2 \\
\hline $\mathrm{pH}$ & & 0.317 & -0.081 \\
\hline $\mathrm{T}\left({ }^{\circ} \mathrm{C}\right)$ & & -0.335 & 0.015 \\
\hline TOC (\%) & & -0.250 & -0.221 \\
\hline $\mathrm{Na}^{+}$ & & 0.337 & 0.041 \\
\hline $\mathrm{Cl}^{-}$ & & 0.189 & 0.056 \\
\hline $\mathrm{Ca}^{2+}$ & & 0.229 & -0.274 \\
\hline $\mathrm{K}^{+}$ & & 0.269 & -0.202 \\
\hline $\mathrm{Mg}^{2+}$ & & 0.333 & 0.058 \\
\hline $\mathrm{NO}_{3}^{-}$ & & -0.290 & 0.135 \\
\hline $\mathrm{SO}_{4}^{2-}$ & & 0.167 & 0.337 \\
\hline $\mathrm{S}^{2-}$ & & -0.028 & -0.322 \\
\hline $\mathrm{Zn}$ & & 0.185 & -0.104 \\
\hline $\mathrm{Pb}$ & & -0.159 & 0.299 \\
\hline $\mathrm{Cd}$ & & -0.132 & 0.345 \\
\hline $\mathrm{Cu}$ & & 0.080 & -0.376 \\
\hline Gravel (\%) & & 0.253 & 0.251 \\
\hline Sand (\%) & & -0.256 & -0.244 \\
\hline Mud (\%) & & -0.120 & -0.319 \\
\hline
\end{tabular}

Bold values were considered high $(\geq|0.290|)$.
TABLE 3 | Taxonomic list of total fauna occurring at Secca delle Fumose, with abundance $(\mathrm{N})$ of each taxon at each site $(\mathrm{H}$ - White hydrothermal vent; $\mathrm{G}$ Geyser; CN - Control North; CS - Control South).

\begin{tabular}{lcccc}
\hline TAXA & H & G & CN & CS \\
\hline Nemertea & - & - & 5 & - \\
Sipuncula & - & 71 & 58 & 477
\end{tabular}

\section{Polychaeta}

Amphictene auricoma (O. F. Müller, 1776)

Aphelochaeta marioni (Saint-Joseph, 1894)

Aphelochaeta multibranchis (Grube, 1863)

Aponuphis bilineata (Baird, 1870)

Capitella capitata (Fabricius, 1780)

Chrysopetalum debile (Grube, 1855)

Dialychone acustica (Claparède, 1870)

Diplocirrus glaucus (Malmgren, 1867)

Drilonereis filum (Claparède, 1868)

Eteone longa (Fabricius, 1780)

Euclymene oerstedi (Claparède, 1863)

Eulalia sp.

Eunice pennata (Müller, 1776)

Eunice vittata (Delle Chiaje, 1828)

Exogone sp.

Glycera unicornis (Lamarck, 1818)

Harmothoe longisetis (Grube, 1863)

Hesionidae indet.

Hydroides dianthus (Verrill, 1873)

Hydroides uncinata (Phillipi, 1844)

Laonice cirrata (M. Sars, 1851)

Lepidonotus clava (Montagu, 1808)

Levinsenia gracilis (Tauber, 1879)

Lumbrineris latreilli (Audouin and Milne-Edwards, 1834)

Lysidice unicornis (Grube, 1840)

Malmgrenia andreapolis (McIntosh, 1874)

Mysta picta (Quatrefages, 1866)

Neanthes kerguelensis (Mclntosh, 1885)

Nereis rava (Ehlers, 1868)

Notomastus latericeus (Sars, 1851)

Owenia fusiformis (Delle Chiaje, 1844)

Perinereis cultrifera (Grube, 1840)

Phyllodoce lineata (Claparède, 1870)

Pista cristata (Müller, 1776)

Platynereis dumerilii (Audouin and Milne Edwards, 1833)

Pontogenia chrysocoma (Baird, 1865)

Protocirrineris chrysoderma (Claparède, 1868)

Protodorvillea kefersteini (McIntosh, 1869)

Pseudoleiocapitella fauveli (Harmelin, 1964)

Sabellidae indet.

Serpula vermicularis (Linnaeus, 1767)

Sigambra tentaculata (Treadwell, 1941)

Spio filicornis (Müller, 1776)

Spiophanes bombyx (Claparède, 1870)

Spirobranchus triqueter (Linnaeus, 1758)

Sthenelais limicola (Ehlers, 1864)

Syllidae indet.

Polyplacophora

Acanthochitona crinita (Pennant, 1777)

Acanthochitona fascicularis (Linnaeus, 1767)
CS
-
477

- $1-$

- 7 -

$-4 \quad-$

$\begin{array}{lll}3 & 26 & 53\end{array}$

4 - - -

- $\quad 11$

- 9 -

- 1 -

- 1 -

- 4 -

- 5 -

$-32$

- $\quad-\quad 45$

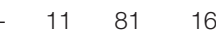

- 3 -

$-\quad-122$

233

$\begin{array}{ll}2 & 2 \\ - & 7\end{array}$

$1-$

- 1 -

- -2

$-\quad 7-$

- 7 -

$\begin{array}{lll}4 & 40\end{array}$

- 3 -

- 7 -

- $\quad-\quad 5$

- 614 -

6
$-\quad 1$

$-\quad 20-$

$7 \quad-\quad$

- 5 -

- 18 -

$19-$

- $\quad-1$

- 4 -

- 9 -

- 1 -

- 4 -

$3 \quad 1-$

$-3-$

- -

- $-\quad$

5 - -

$-1$

$-16 \quad 3$
$-\quad 16$

1
$-\quad-\quad 1$

- $\quad 11$

(Continued)
- 1 - 
TABLE 3 | Continued

TAXA
Callochiton septemvalvis (Montagu, 1803)
Leptochiton scabridus (Jeffreys, 1880)
Lepidochitona sp.
Gastropoda

Alvania cancellata (da Costa, 1778)

Alvania discors (Allan, 1818)

Alvania lineata (Risso, 1826)

Alvania pagodula (Bucquoy, Dautzenberg, and Dollfus, 1884)

Aplysia parvula (Mörch, 1863)

Ascobulla fragilis (Jeffreys, 1856)

Bela nebula (Montagu, 1803)

Bittium latreillii (Payraudeau, 1826)

Bolma rugosa (Linnaeus, 1767)

Bulla striata (Bruguière, 1792)

Caecum auriculatum (de Folin, 1868)

Caecum glabrum (Montagu, 1803)

Caecum sp.

Caecum trachea (Montagu, 1803)

Calyptraea chinensis (Linnaeus, 1758)

Cerithium vulgatum (Bruguière, 1792)

Chrysallida indistincta (Henn and Brazier, 1894)

Eulimella sp.

Euspira nitida (Donovan, 1804)

Fusinus sp.

Gibbula ardens (Salis Marschlins, 1793)

Gibbula fanulum (Gmelin, 1791)

Gibbula guttadauri (Philippi, 1836)

Gibbula sp.

Haminoea sp.

Hexaplex trunculus (Linnaeus, 1758)

Mangelia costulata (Risso, 1826)

Mangelia scabrida (Monterosato, 1890)

Manzonia crassa (Kanmacher, 1798)

Odostomia sp.

Ondina vitrea (Brusina, 1866)

Philine sp.

Rissoa splendida (Eichwald, 1830)

Tectura virginea (O. F. Müller, 1776)

Tritia cuvierii (Payraudeau, 1826)

Tritia incrassata (Strøm, 1768)

Pusia savignyi (Payraudeau, 1826)

Pusia tricolor (Gmelin, 1791)

Vitreolina sp.

Weinkauffia turgidula (Forbes, 1844)

Williamia gussoni (Costa O. G., 1829)

\section{Bivalvia}

\section{Arca noae (Linnaeus, 1758)}

Asbjornsenia pygmaea (Lovén, 1846)

Cardites antiquatus (Linnaeus, 1758)

Centrocardita aculeata (Poli, 1795)

Centrocardita sp.

Ctena decussata (O. G. Costa, 1829)

Dosinia exoleta (Linnaeus, 1758)

Flexopecten hyalinus (Poli, 1795)

Gari costulata (W. Turton, 1822)

$\begin{array}{cccc}\text { H } & \text { G } & \text { CN } & \text { CS } \\ - & 1 & - & - \\ - & - & 1 & - \\ - & 1 & 10 & 21\end{array}$

- $1-$

$\begin{array}{llll}1 & 3 & 1 & -\end{array}$

- $5--$

- $-\quad-1$

- $\quad-\quad 1$

- 16

- -1 -

- 519

- $\quad-\quad 1$

- $1-$ -

- $1-6$

- 1 -

- - - 26

- 14

- 138

- 111

- - - 1

- 1 -

- 1 -

- - - 3

- 11 -

- - - 1

- 31

- 1 -

$1-\quad-10$

- $-\quad 5$

- 2

- $1-$

- 1 -

- - - 1

- 2 -

- 14

- 1 -

- -1 -

$815-$ -

$-7--$

- $-\quad-2$

- $\quad$ - 1

- $-\quad-1$

- - - 1

- $-\quad-2$

- 1 - 1

- 10 -

- -3

- 22

-12824
-12

- -49

- -1 -

- 1 -

- 52
TABLE 3 | Continued

\begin{tabular}{lllll}
\hline TAXA & H & G & CN & CS
\end{tabular}

Gari tellinella (Lamarck, 1818)

Glans trapezia (Linnaeus, 1767)

Gouldia minima (Montagu, 1803)

Gregariella semigranata (Reeve, 1858)

Hiatella arctica (Linnaeus, 1767)

Kurtiella bidentata (Montagu, 1803)

Laevicardium crassum (Gmelin, 1791)

Limaria tuberculata (Olivi, 1792)

Loripinus fragilis (Philippi, 1836)

Lucinella divaricata (Linnaeus, 1758)

Modiolula phaseolina (Philippi, 1844)

Moerella donacina (Linnaeus, 1758)

Musculus costulatus (Risso, 1826)

Musculus subpictus (Cantraine, 1835)

Papillicardium papillosum (Poli, 1791)

Peronidia albicans (Gmelin, 1791)

Polititapes aureus (Gmelin, 1791)

Rocellaria dubia (Pennant, 1777)

Striarca lactea (Linnaeus, 1758)

Thracia villosiuscula (MacGillivray, 1827)

Venus verrucosa (Linnaeus, 1758)

Amphipoda

Ampithoe ramondi (Audouin, 1826)

Apherusa chiereghinii (Giordani- Soika, 1949)

Caprellidae

Dexamine spinosa (Montagu, 1813)

Gammarus sp.

Microdeutopus anomalus (Rathke, 1843)

Microdeutopus spp.

Pereionotus testudo (Montagu, 1808)

Pseudolirius kroyeri (Haller, 1897)

Perioculodes sp.

\section{Decapoda}

Alpheus glaber (Olivi, 1792)

Anapagurus bicorniger (A. Milne-Edwards and Bouvier, 1892)

Athanas nitescens (Leach, 1813)

Clibanarius erythropus (Latreille, 1818)

Ebalia deshayesi (Lucas, 1846)

Eriphia verrucosa (Forskål, 1775)

Galathea sp.

Lysmata seticaudata (Risso, 1816)

Necallianassa truncata (Giard and Bonnier, 1890)

Paguristes eremita (Linnaeus, 1767)

Pagurus cuaensis (Bell, 1844)

Pagurus sp.

Pisa armata (Latreille, 1803)

Processa macrophthalma (Nouvel and Holthuis, 1957)

Sirpus zariquieyi (Gordon, 1953)

Synalpheus gambarelloides (Nardo, 1847)

Upogebia stellata (Montagu, 1808)

Xantho pilipes (A. Milne-Edwards, 1867)

Isopoda

Anthuridae

Cymodoce truncata (Leach, 1814)

Kupellonura mediterranea (Barnard, 1925)

- $\quad 1 \quad$

- $\quad 110$

- 1521

- 1219

- 40571

- $\quad 178$

- $1-$

- $11-$

- -12

- $1-$

- 1 -

- 52

- 7 -

- 43

- $1-$

- - - 1

- 135

- 213

- 5311

- 1 -

- 8714

- $1-$

- 1 -

- $-\quad 4$

- 37

- 29

- 1 -

- 21

- 612

- 1 -

- 1 -

- 2135

- 2 -

- 4 - -

- $\quad 15$

- 1 - -

- $2-3$

- 2 -

- 1 -

- $-\quad-1$

- 3 - -

$1--$

- $\quad$ - 1

- 1 - 1

- 12

- 1 -

- 2 -

- 4 -

- 316

- 1147

- 12 - $\begin{array}{llll}- & - & 1 & - \\ 1 & - & -\end{array}$ 
TABLE 3 | Continued

\begin{tabular}{|c|c|c|c|c|}
\hline TAXA & $\mathbf{H}$ & G & CN & CS \\
\hline \multicolumn{5}{|l|}{ Tanaidacea } \\
\hline Chondrochelia savignyi (Kroyer, 1842) & - & - & 2 & 10 \\
\hline \multicolumn{5}{|l|}{ Cumacea } \\
\hline ind. & - & - & 5 & - \\
\hline \multicolumn{5}{|l|}{ Echinoidea } \\
\hline Echinocyamus pusillus (O. F. Müller, 1776) & - & - & 7 & 7 \\
\hline \multicolumn{5}{|l|}{ Holothuroidea } \\
\hline indet. & - & - & 2 & 2 \\
\hline \multicolumn{5}{|l|}{ Ophiuroidea } \\
\hline Ophiothrix sp. & - & 1 & - & 3 \\
\hline Amphipholis sp. & - & 3 & 4 & 11 \\
\hline Platyhelminthes & - & - & 1 & - \\
\hline \multicolumn{5}{|l|}{ Chordata } \\
\hline Branchiostoma lanceolatum (Pallas, 1774) & - & - & 6 & 1 \\
\hline
\end{tabular}

Dashes indicate absence.

different taxonomic levels as follows: Mollusca (610 ind.), Sipuncula (606 ind.), Polychaeta (513 ind.), Crustacea (172 ind.), Echinodermata (40 ind.), Chordata (7 ind.), Nemertea (5 ind.), and Platyhelminthes (1 ind.) (Table 3). The whole benthic community drastically increased in abundance and species richness away from the vent sites $(\mathrm{H}$ : $\mathrm{DI}=0.97 \%-$ $\mathrm{DQ}=5.49 \%$; $\mathrm{:}: \mathrm{DI}=13.20 \%-\mathrm{DQ}=29.88 \%)$ to control sites $(\mathrm{CN}$ : $\mathrm{DI}=31.58 \%-\mathrm{DQ}=68.29 \%$; CS: $\mathrm{DI}=54.25 \%-\mathrm{DQ}=48.78 \%$ ).

The main taxa structuring the benthic community were Mollusca, Sipuncula, Polychaeta and Crustacea, reaching a dominance of $97.28 \%$. With the only exception of Sipuncula, three taxa were detected at all sites, differentially contributing to the communities living at each site (Figure 5).

Mollusca showed the highest species richness, being represented by 76 species, belonging to the classes Polyplacophora, Gastropoda, and Bivalvia. Bivalvia was the dominant group in term of abundance (Figure 5A), with 400 individuals (65.57\%) belonging to 30 species $(39.47 \%)$. Gastropods were the dominant group in term of species richness (Figure 5B), with 41 species (53.94\%) and an abundance of 173 individuals (28.36\%). Polyplacophores were poorly represented, both in abundance (37 ind.; 6.06\%) and species richness (5 sp.; 6.57\%).

The highest percentage of mollusks abundance mainly occurred in the control site CS (52.46\%), where bivalves were mainly represented by the species Hiatella arctica (76 ind.), gastropods by Caecum sp. (26 ind.) and polyplacophores by Lepidochitona sp. (31 ind.). On the other hand, the lowest percentage of mollusks occurred in H (DI 1.64\%) with only three species: Tritia cuvierii (8 ind.), Haminoea sp. (1 ind.), and Alvania discors (1 ind.).

Polychaeta, with a total of 513 individuals belonging to 47 species, were mainly represented by the species Eunice vittata (108 ind., 21.05\%) and Aponuphis bilineata (83 ind., 16.18\%). This group was dominant in the control site CN (Figures 5C,D), both in abundance (307 ind., 59.84\%) and in species richness (36 sp., 76\%). The opposite occurred in $\mathrm{H}$, where a total of only seven individuals belonging to four species, among which four individuals of the polychaete Capitella capitata, were recorded.

Crustacea were represented by 172 individuals belonging to 33 species, grouped in five orders: Decapoda, Isopoda, Tanaidacea, Amphipoda, and Cumacea. Only five species, represented by the decapod Anapagurus bicorniger, the amphipods Dexamine spinosa and Pereionotus testudo, the isopods Cymodoce truncata and Anthuridae indet., reached a dominance of $52.35 \%$ of the total crustacean assemblage. The highest percentage of crustaceans individuals was detected in CS (84 ind., 48.84\%; Figure 5E) and species richness in CN (20 sp., 60.61\%; Figure 5F), while only 2 species, the decapod Pagurus sp. and the amphipod Perioculodes sp., occurred in $\mathrm{H}$ with only 1 individual.

Among the sinecological indices (Table 4), the highest density (N) and species richness (SR) values were recorded in CN and CS, while the lowest values in $\mathrm{H}$, which also showed the lowest values of diversity $\left(\mathrm{H}^{\prime}\right)$ and evenness $(\mathrm{J})$. For each index, PERMANOVA test highlighted significant differences among sites, except for Pielou's evenness (J) (Table 4). A significant difference was also detected analyzing macrofauna composition (PERMANOVA: $F=3.411, p=0.0004)$. In particular, pairwise comparisons showed differences between hydrothermal vents $(G ; H)$ and non-vents ( $\mathrm{CN}$; CS) sites, with the highest average similarity among these latter sites (Average similarity 38.30\%; Table 5). These differences were also evident in the plot of CAP analysis (Figure 6), where the three replicates formed consistent clusters for each site. Along the CAP1 axis, vent sites ( $\mathrm{H}$ and $\mathrm{G})$ were separated from control ones (CN and CS), while along the CAP2 axis the graph showed a clear separation between the southern $(\mathrm{H}$ and $\mathrm{CS}$ ) and northern ( $\mathrm{G}$ and $\mathrm{CN}$ ) sites. In particular, H and $\mathrm{G}$ were strongly polarized respectively in the positive and negative part of CAP2, while CN and CS were aggregated around the zero value of CAP2, respectively in the positive and negative part. The average multivariate similarity of macrofaunal assemblage composition for each site ranged from 11.94 to 59.92\% (Table 6), while the similarity of dominant species among sites was $19.62 \%$, attributable to sipunculans, mollusks, and polychaetes (Table 7).

\section{Relationship Between Environmental Variables and Macrobenthic Community}

The pattern of community structure was significantly correlated with some environmental parameters of sediments and interstitial waters (Table 8) and visualized in the dbRDA (Figure 7), where vectors indicate the direction of increasing influence of each variable on community changes.

Concerning the first group of variables (Table 8A - Marginal tests), gravel, sand, $\mathrm{pH}$, temperature, and TOC explained a significant variation in benthic community when tested individually. In particular, only gravel and $\mathrm{pH}$ represented the most important driving factors influencing benthic community distribution among sites (Table 8A - Sequential tests), explaining $52.76 \%$ of community variation.

As for interstitial water variables, all the investigated ions, with the only exception of $S^{2-}$ in the site $G$, had a significant effect on community variability (Table $\mathbf{8 B}$ - Marginal tests), even 


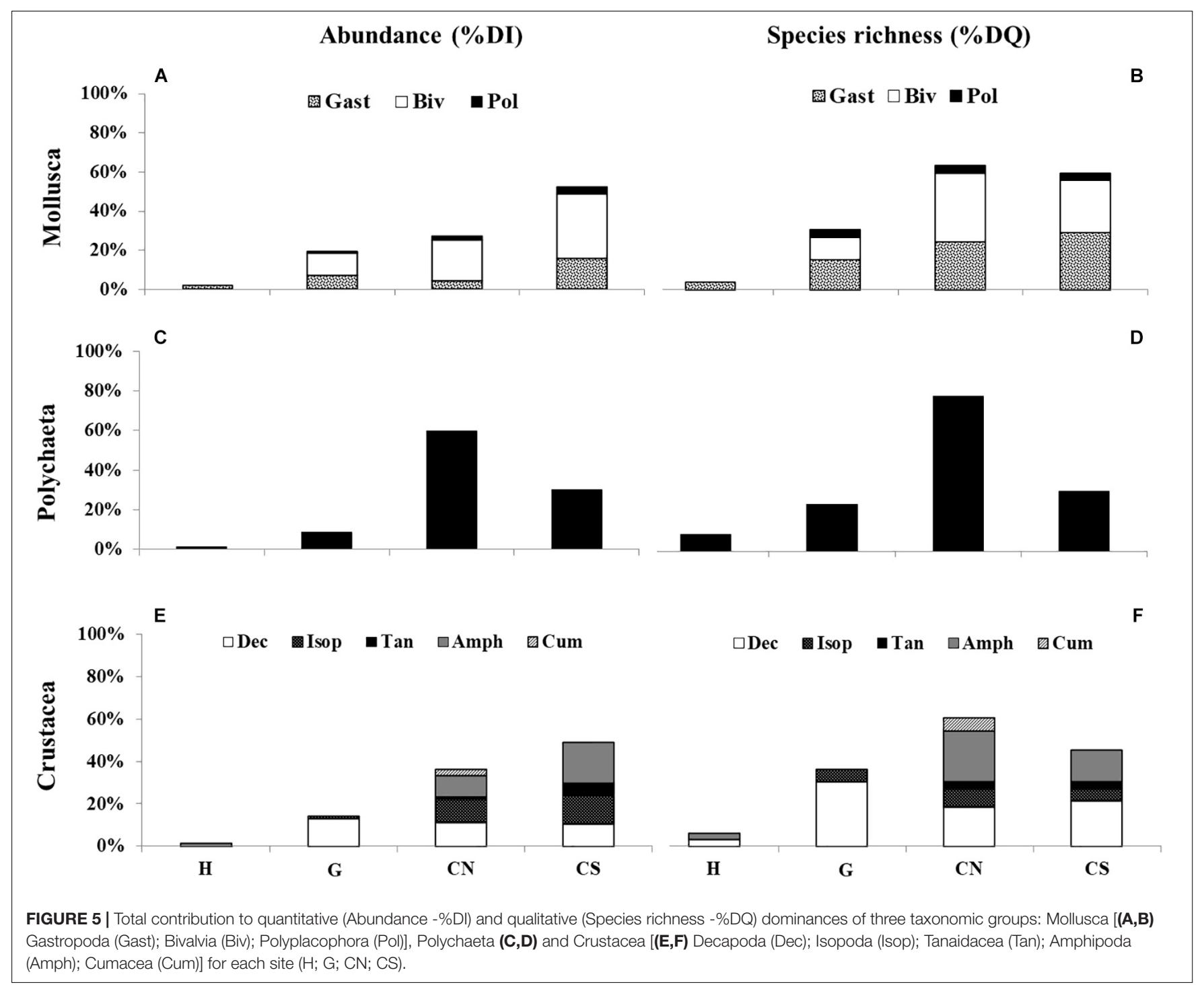

though the greatest influence was due to the $\mathrm{Mg}^{2+}, \mathrm{K}^{2+}$, and $\mathrm{Ca}^{2+}$ ions (Table 8B - Sequential tests), which explained 56.63\% of community variation.

\section{TABLE 4 | Macrofauna assemblage.}

\begin{tabular}{lcccc}
\hline Site & SR & $\mathbf{N}$ & $\mathbf{J}$ & $\mathbf{H}^{\prime}$ \\
\hline $\mathrm{H}$ & $3.33 \pm 2.08$ & $6.33 \pm 5.03$ & $0.56 \pm 0.48$ & $1.22 \pm 1.07$ \\
$\mathrm{G}$ & $24 \pm 12.16$ & $86 \pm 50.68$ & $0.78 \pm 0.05$ & $3.47 \pm 0.82$ \\
$\mathrm{CN}$ & $63 \pm 5.29$ & $205.66 \pm 50.52$ & $0.87 \pm 0.01$ & $5.23 \pm 0.18$ \\
$\mathrm{CS}$ & $51.33 \pm 10.78$ & $353.33 \pm 107.77$ & $0.64 \pm 0.05$ & $3.63 \pm 0.37$ \\
$F$ & 29.31 & 16.314 & 0.958 & 16.28 \\
$p$ (perm) & 0.0006 & 0.0004 & 0.473 & 0.001 \\
\hline
\end{tabular}

Number of individuals (N) per $25 d m^{3}$, species richness (SR), Shannon-Weaver diversity $\left(H^{\prime}\right)$ and Pielou's evenness $(J)$ measured for each site $(H ; G ; C N$; CS) (mean $\pm S D$ ), and results of PERMANOVA test on Euclidean distance [F: F-value, p(perm): calculated probability value, Unique perms: the number of unique permutations].

\section{DISCUSSION}

The hydrothermal vent system at Pozzuoli Bay provides an opportunity to study the macrobenthic assemblages and composition in a shallow extreme environment. Through this work, the macrobenthic community at Secca delle Fumose was investigated for the first time. The results highlighted a strong

TABLE 5 | Results of PERMANOVA pairwise comparisons among sites, using 4999 permutations, and average similarity between sites.

\begin{tabular}{llclc}
\hline Site & \multicolumn{1}{c}{$\boldsymbol{t}$} & Unique perms & $\boldsymbol{p}(\mathbf{M C )}$ & Average similarity (\%) \\
\hline $\mathrm{H}, \mathrm{G}$ & 1.4325 & 10 & 0.1286 & 7.66 \\
$\mathrm{H}, \mathrm{CN}$ & 1.9607 & 10 & 0.0344 & 0.75 \\
$\mathrm{H}, \mathrm{CS}$ & 2.013 & 10 & 0.0378 & 1.28 \\
$\mathrm{G}, \mathrm{CN}$ & 1.9645 & 10 & 0.038 & 18.83 \\
G, CS & 1.8827 & 10 & 0.0416 & 24.18 \\
$\mathrm{CN}, \mathrm{CS}$ & 2.0479 & 10 & 0.0236 & 38.30
\end{tabular}




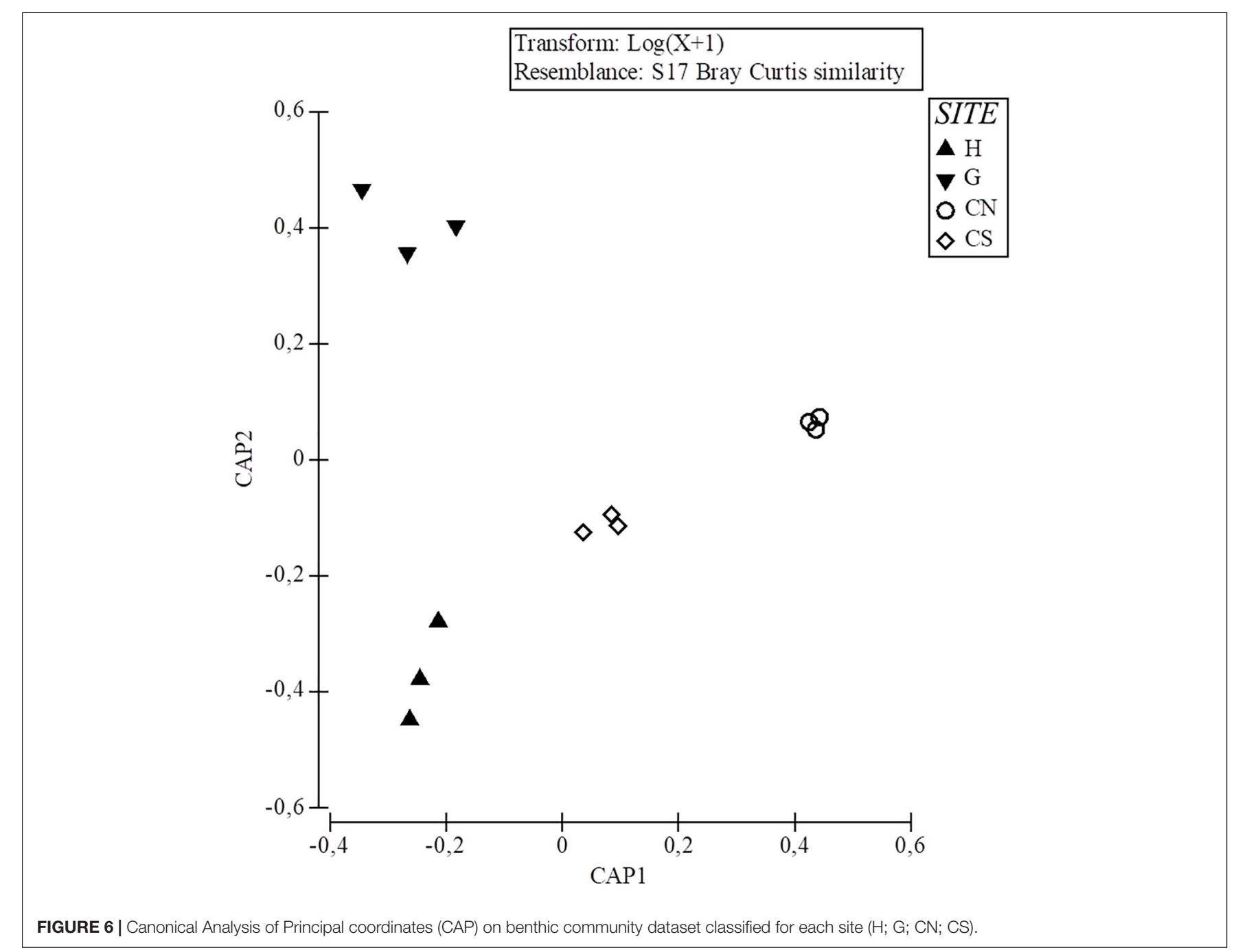

change in density, species richness and diversity between two non-vent ( $\mathrm{CN}$ and $\mathrm{CS}$ ) and two different vent ( $\mathrm{H}$ and $\mathrm{G})$ sites.

When compared to the hydrothermal sites, the control sites showed higher abundance and species richness, and the environment was characterized by normal $\mathrm{pH}$ and ions concentrations (e.g., $\mathrm{Ca}^{2+}, \mathrm{K}^{2+}$, and $\mathrm{Mg}^{2+}$ ), and by a significant percentage of gravelly sediment that markedly affected the macrobenthic composition (DistLM Table 6; dbRDA Figure 7).

It is well-known that benthic species are functionally and structurally related to the main features of the habitat they reside (e.g., Woodin, 1978; Thrush et al., 1991; Desprez, 2000; Riera et al., 2012; Donnarumma et al., 2018; Casoli et al., 2019). In particular, the taxa composition recorded in the control sites was consistent with a marked occurrence of gravel, which offers microhabitats suitable for settlement and refuge. This is also proven by the high dominance of the byssate bivalve $H$. arctica, which is commonly found on hard substrates, where become strictly aggregated in dense groups (Purchon, 1977). The occurrence of high abundance of gastropod Caecum spp. is probably due to the presence of sand in the sediment with only tracks of mud (Fretter and Graham, 1978). Species belonging to the genus Eunice (Annelida, Polychaeta) also occurred with a very high abundance in the control area, in agreement with their cosmopolitan nature (George and Hartmann-Schröder, 1985; Dounas and Koukouras, 1989; Gusso et al., 2001; Fauchald et al., 2009), as well as for the crevicedwelling isopod C. truncata and sipunculans, capable of hiding in the narrow cracks of rocks and in empty or fragmented shells (Ferrero-Vicente et al., 2013).

In addition to the relationship between benthic assemblages and structural characteristics of the substrate, the understanding of environment state is also related to the occurrence of sensitive or tolerant species to the environmental changes (Simboura and Zenetos, 2002; Washburn et al., 2016). For instance, the high abundance of $C$. truncata restricted only in the control area might be related to the suitable habitat conditions, as reported for the normal pH conditions at Ischia Island by Cigliano et al. (2010). Conversely, the absence of this species at the geyser site $(\mathrm{G})$ may be due to the crustaceans sulfide sensitivity (Gray et al., 2002), as well as its absence in the white hydrothermal vent $(\mathrm{H})$ could be also related to the metabolic sensitivity of $C$. truncata to high $p \mathrm{CO}_{2}$ condition (Turner et al., 2016). 
TABLE 6 | Results of similarity of percentages test, showing dominant species mostly responsible for the similarity among replicates for each site (Cum\%-50\% cut-off).

\begin{tabular}{|c|c|c|c|c|c|c|}
\hline Average similarity & Taxa & Av.Abund & Av.Sim & $\mathrm{Sim} / \mathrm{SD}$ & Contrib\% & Cum.\% \\
\hline \multirow[t]{10}{*}{ CS - 59.92\% } & SIPUNCULA & 5.04 & 6.97 & 12.35 & 11.63 & 11.63 \\
\hline & Hiatella arctica & 3.07 & 3.75 & 9.60 & 6.25 & 17.88 \\
\hline & Aponuphis bilineata & 2.77 & 3.33 & 3.49 & 5.56 & 23.44 \\
\hline & Centrocardita sp. & 2.18 & 2.93 & 13.48 & 4.89 & 28.34 \\
\hline & Eunice pennata & 2.44 & 2.65 & 1.32 & 4.43 & 32.77 \\
\hline & Lysidice unicornis & 1.95 & 2.39 & 2.71 & 3.99 & 36.75 \\
\hline & Gouldia minima & 1.97 & 2.25 & 9.98 & 3.75 & 40.51 \\
\hline & Lepidochitona sp. & 1.87 & 1.89 & 5.46 & 3.15 & 43.66 \\
\hline & Amphipholis sp. & 1.50 & 1.84 & 3.87 & 3.07 & 46.73 \\
\hline & Haminoea cf hydatis & 1.44 & 1.81 & 8.19 & 3.02 & 49.75 \\
\hline \multirow[t]{11}{*}{$\mathrm{CN}-54.53 \%$} & Eunice vittata & 3.25 & 3.88 & 56.62 & 7.11 & 7.11 \\
\hline & SIPUNCULA & 2.99 & 3.76 & 71.54 & 6.90 & 14.01 \\
\hline & Centrocardita sp. & 2.30 & 2.81 & 5.43 & 5.14 & 19.16 \\
\hline & Aponuphis bilineata & 2.19 & 2.50 & 57.02 & 4.59 & 23.75 \\
\hline & Owenia fusiformis & 2.02 & 2.50 & 57.02 & 4.59 & 28.34 \\
\hline & Pista cristata & 1.92 & 2.30 & 6.52 & 4.22 & 32.56 \\
\hline & Polititapes aureus & 1.65 & 1.95 & 6.69 & 3.58 & 36.14 \\
\hline & Cymodoce truncata & 1.69 & 1.94 & 56.62 & 3.55 & 39.69 \\
\hline & Glycera unicornis & 1.57 & 1.85 & 13.34 & 3.39 & 43.08 \\
\hline & Hesionidae indet. & 1.19 & 1.46 & 13.34 & 2.68 & 45.77 \\
\hline & Musculus costulatus & 1.19 & 1.46 & 13.34 & 2.68 & 48.45 \\
\hline \multirow[t]{2}{*}{$S-32.10 \%$} & SIPUNCULA & 2.93 & 8.68 & 5.96 & 27.05 & 27.05 \\
\hline & Hiatella arctica & 2.23 & 4.49 & 1.59 & 13.99 & 41.04 \\
\hline $\mathrm{H}-11.94 \%$ & Tritia cuvierii & 1.07 & 11.94 & 0.58 & 100 & 100 \\
\hline
\end{tabular}

Heavy metals ( $\mathrm{Zn}, \mathrm{Cd}, \mathrm{Pb}$, and $\mathrm{Cu}$ ) occurred in the interstitial waters of sediments at all sampling sites (Table 1). However, their low quantity is compatible with the existence of a well-structured macrobenthic assemblage in the control sites, as reported in previous investigations (Bryan, 1976; Yoshida et al., 2002; Raghukumar et al., 2008). Moreover, the presence only in the

TABLE 7 | Results of similarity of percentages test, showing taxa that mostly contributed to similarity among sites.

\begin{tabular}{lccccc}
\hline Taxa & Av.Abund & Av.Sim & Sim/SD & Contrib\% & Cum.\% \\
\hline $\begin{array}{l}\text { SIPUNCULA } \\
\text { MOLLUSCA }\end{array}$ & 2.74 & 2.98 & 1 & 15.19 & 15.19 \\
$\begin{array}{l}\text { Tritia cuvierii } \\
\text { (Payraudeau, 1826) }\end{array}$ & 0.6 & 1.44 & 0.26 & 7.34 & 22.53 \\
$\begin{array}{l}\text { Hiatella arctica } \\
\text { (Linnaeus, 1767) }\end{array}$ & 1.52 & 1.27 & 0.67 & 6.48 & 29.01 \\
$\begin{array}{l}\text { POLYCHAETA } \\
\text { Aponuphis bilineata }\end{array}$ & 1.45 & 1.26 & 0.97 & 6.43 & 35.44 \\
$\begin{array}{l}\text { (Baird, 1870) } \\
\begin{array}{l}\text { Eunice vittata (Delle } \\
\text { Chiaje, 1828) }\end{array}\end{array}$ & 1.45 & 0.95 & 0.64 & 4.84 & 40.28 \\
$\begin{array}{l}\text { MOLLUSCA } \\
\text { Centrocardita sp. }\end{array}$ & 1.18 & 0.78 & 0.63 & 3.97 & 44.25 \\
$\begin{array}{l}\text { POLYCHAETA } \\
\text { Lysidice unicornis }\end{array}$ & 0.87 & 0.69 & 0.74 & 3.52 & 47.76 \\
\begin{tabular}{l} 
Grube, 1840) \\
\hline
\end{tabular} & & & & & \\
\hline
\end{tabular}

Average similarity: $19.62 \%$; Cum\%-50\% cut-off. control sites of the cephalochordate Branchiostoma lanceolatum attests to the good quality of the sites, since it is a species sensitive to organic enrichment and polluted water (Simboura and Zenetos, 2002; Rota et al., 2009).

At the two hydrothermal sites ( $\mathrm{G}$ and $\mathrm{H}$ ), a drastic decrease of benthic biodiversity was observed. This can be mainly attributable to environmental conditions, in particular to presence of sulfide, high temperatures and seawater $\mathrm{pH}$ variations generated by volcanic activity. Moreover, as observed by Tarasov et al. (2005), the hydrothermal fluids in these sites produced a slight reduction of water salinity, measured as $\mathrm{Na}^{+}$and $\mathrm{Cl}^{-}$ions.

Several studies (e.g., Thiermann et al., 1997; Tarasov et al., 1999; Dando, 2010) have reported a decrease of both density and diversity of benthic communities as corresponding to the occurrence of high temperatures and sulfide concentrations, leading to an increase of temperature- and/or sulfide-tolerant species. The same result was also found in the present study where high sediment temperatures and sulfide ions $\left(\mathrm{S}^{2-}\right)$ occurred at the geyser site $(G)$, resulting in a $69 \%$ reduction of taxonomic richness and a 73\% reduction in number of individuals compared to control sites. At this geyser site we observed the absence of obligate vent-associated species, which were previously reported for deep-sea vent systems (Tarasov et al., 2005 and reference therein; Schander et al., 2010; Stevens et al., 2015). Our data are consistent with results from other coastal shallow water hydrothermal vents (Dando, 2010; Bianchi et al., 2011). In particular, the fauna around the geyser at the Secca delle Fumose was composed by the most representative species inhabiting the 'background' area (e.g., the polychaetes E. vittata and A. bilineata, 
TABLE 8 | DistLM results comparing benthic community data and environmental variables (A,B).

\begin{tabular}{|c|c|c|c|c|c|c|c|}
\hline \multirow[t]{2}{*}{ VARIABLES } & \multicolumn{3}{|c|}{ Marginal tests } & \multicolumn{4}{|c|}{ Sequential tests } \\
\hline & Pseudo-F & $p$ & $\begin{array}{c}\text { Proportion of } \\
\text { variation explained }\end{array}$ & Pseudo-F & $p$ & $\begin{array}{c}\text { Proportion of } \\
\text { variation explained }\end{array}$ & $\begin{array}{c}\text { Cumulative } \\
\text { variation }\end{array}$ \\
\hline \multicolumn{8}{|c|}{ (A) Sediment variables } \\
\hline Gravel (\%) & 3.3023 & 0.0028 & 0.24825 & 3.3023 & 0.0024 & 0.24825 & 0.24825 \\
\hline Sand (\%) & 3.3547 & 0.0032 & 0.2512 & 1.6102 & 0.0954 & 0.11409 & 0.36234 \\
\hline Mud (\%) & 1.5694 & 0.0956 & 0.13565 & 0 & 1 & $1.45 \mathrm{E}-15$ & 0.36234 \\
\hline $\mathrm{pH}$ & 3.408 & 0.0068 & 0.25418 & 2.7984 & 0.0042 & 0.16525 & 0.52759 \\
\hline Temperatures $\left({ }^{\circ} \mathrm{C}\right)$ & 4.7266 & 0.0002 & 0.32096 & 1.9971 & 0.0622 & 0.10486 & 0.63245 \\
\hline TOC (\%) & 3.1083 & 0.0056 & 0.23713 & 0.67269 & 0.7442 & 3.71E-02 & 0.6695 \\
\hline \multicolumn{8}{|c|}{ (B) Interstitial water variables } \\
\hline $\mathrm{Ca}^{2+}$ & 2.3312 & 0.0258 & 0.18905 & 2.3312 & 0.0244 & 0.18905 & 0.18905 \\
\hline $\mathbf{K}^{+}$ & 3.2656 & 0.0084 & 0.24617 & 2.2943 & 0.0274 & 0.16474 & 0.35379 \\
\hline $\mathrm{Mg}^{2+}$ & 4.5698 & 0.0006 & 0.31365 & 3.8457 & 0.0014 & 0.20979 & 0.56358 \\
\hline $\mathrm{NO}_{3}^{-}$ & 3.3708 & 0.009 & 0.2521 & 1.0131 & 0.398 & $5.52 \mathrm{E}-02$ & 0.61876 \\
\hline $\mathrm{SO}_{4}{ }^{2-}$ & 2.1855 & 0.034 & 0.17935 & 0.89609 & 0.5072 & 4.95E-02 & 0.6683 \\
\hline $\mathrm{S}^{2-}$ & 1.7078 & 0.0796 & 0.14587 & 0.50382 & 0.8168 & 3.04E-02 & 0.69866 \\
\hline Zn & 1.6187 & 0.1072 & 0.13932 & 1.3074 & 0.2978 & $7.42 \mathrm{E}-02$ & 0.77289 \\
\hline $\mathrm{Pb}$ & 1.6385 & 0.1018 & 0.14078 & 1.3553 & 0.302 & 7.07E-02 & 0.84356 \\
\hline Cd & 1.4394 & 0.1482 & 0.12583 & 1.1787 & 0.3936 & 5.80E-02 & 0.90157 \\
\hline $\mathrm{Cu}$ & 1.3934 & 0.1556 & 0.1223 & 0.76951 & 0.5662 & 4.28E-02 & 0.94438 \\
\hline
\end{tabular}

Bold data are significantly different at $\alpha=0.05$.
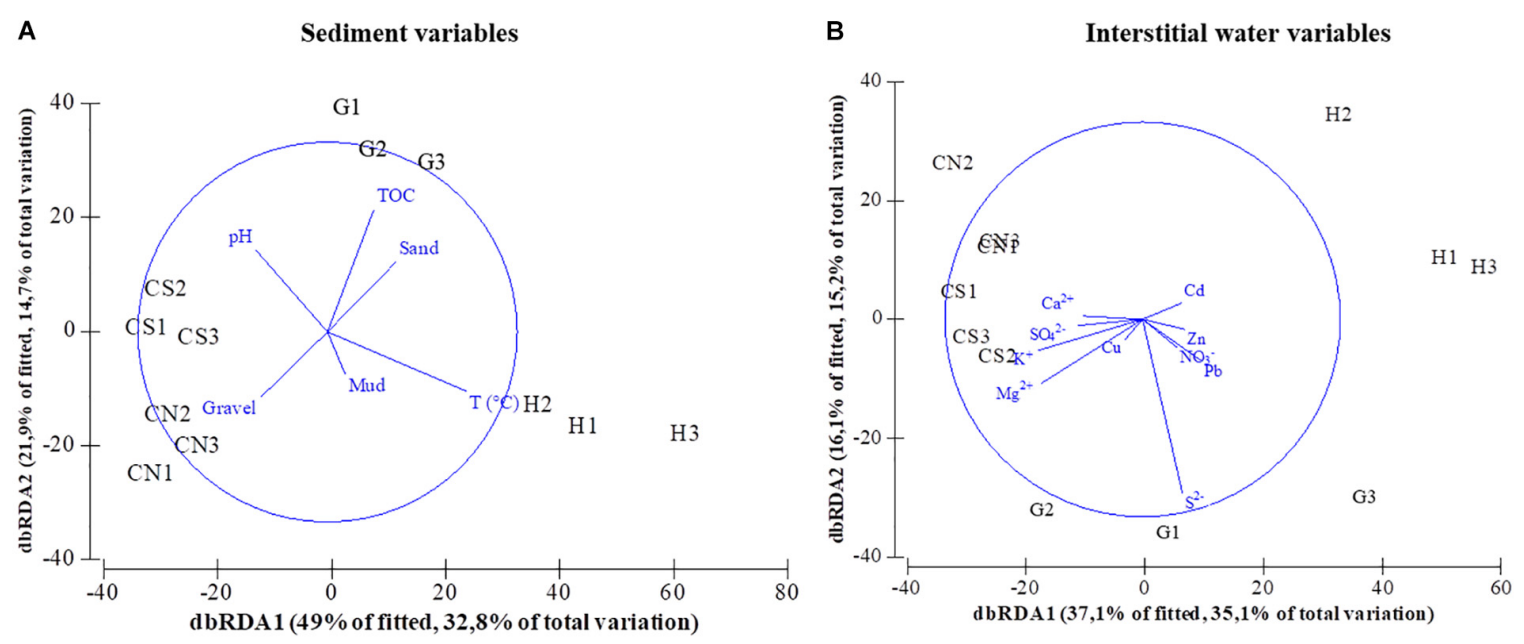

FIGURE 7 | dbRDA plot of benthic community structure fitted to sediment (A) and water variables (B), showing each site replicated (H; G; CN; CS).

the bivalves $H$. arctica and Venus verrucosa, the ophiuroid Amphipholis sp.), but with a very low number of individuals. This benthic assemblage may represent a "simplified" community as suggested by Dando (2010), who defined the living fauna around hydrothermal vent and cold seep sites as a subset of the background biota.

According to Thiermann et al. (1997), the harsh hydrothermal conditions drastically affect the macrobenthic composition, as also observed at the "white" hydrothermal site $(\mathrm{H})$. Here, the lowest species richness ( $9 \mathrm{sp}$.) and abundance (19 ind.) are mainly due to the seawater acidification ( $\mathrm{pH} \sim 7.6$ ), in agreement with
Di Napoli et al. (2016) who recently detected acidic $\mathrm{CO}_{2}$-rich fluids in the SdF area, and to the high sediment temperature $\left(37.53 \pm 2.28^{\circ} \mathrm{C}\right)$, that was almost the double of that detected in the control sites $\left(21.8^{\circ} \mathrm{C}\right)$. These factors produced a reduction of $83.64 \%$ in taxonomic richness and $86.29 \%$ in number of individuals if compared with those found around the geyser and a reduction of 93.92 and $97.75 \%$ respectively if compared with control sites.

The dominant species in $\mathrm{H}$ site were the gastropod T. cuvierii (8 ind.) and the opportunistic polychaete C. capitata (4 ind.), while the other species, each occurring with only one individual, 
could be considered very rare in the hydrothermal area. The occurrence of the vagile nassariid gastropod T. cuvierii and the sediment-dwelling polychaete $C$. capitata clearly underlines the faunal similarity of our study area with other shallowwater hydrothermal vents. Indeed, nassariid species Tritia neritea (= Cyclope neritea Linnaeus, 1758), was among the dominant organisms in hydrothermal vents off Milos in the Aegean Sea (Dando et al., 1995; Southward et al., 1997; Thiermann et al., 1997) and in the Papua New Guinea (Tarasov et al., 1999). Population density of nassarids species is often influenced by food availability (Zhao et al., 2011), similarly the high abundance of T. cuvierii in the white hydrothermal site $(\mathrm{H})$ may be due to the high food source consisting in the microbial mat (Cardigos et al., 2005), so as also occurs for the congeneric species T. neritea in other vent systems. High TOC concentration in the sediment (Table 1) might represent a further food source of this gastropod. The organic enrichment could be responsible for the dominance of the opportunistic polychaete C. capitata (Grassle and Grassle, 1976), which is a tolerant species to high temperatures and sulfide concentrations (Gamenick et al., 1998a). This work does not address directly the genetics of C. capitata complex (Blake, 2009; Nygren, 2014) that is also reported in hydrothermal vents and sulfidic habitats (Gamenick et al., 1998a,b), nevertheless such complex of sibling species so as for gastropods (e.g., Colognola et al., 1986) will be the focus of future research on its genetic variation under the extreme environmental conditions occurring in the study area.

\section{CONCLUSION}

This work represents the first study describing the particular environmental conditions and species composition of macrofauna at the Secca delle Fumose shallow hydrothermal system, an easily accessible coastal area, to evaluate the biological responses in an extreme habitat (i.e., characterized by high temperature, sulfide concentration and low $\mathrm{pH}$ condition). The results showed that the studied macrobenthic community appears to be strongly driven by high sediment temperatures, by sulfide concentration around the geyser and by low $\mathrm{pH}$ value in the white microbial mat area with the occurrence of some $\mathrm{CO}_{2}$ gas bubbling. These key factors led to a drastic reduction of biodiversity, compared to the surrounding nonvent area, highlighting the great importance of environmental state in structuring benthic systems. Future studies should also take into account other key elements of ecosystem functioning, such as meiofauna and microfauna communities, for a better understanding of the complex characteristics related to this very shallow extreme environment of the Campi Flegrei area.

\section{REFERENCES}

Anderson, M., Gorley, R. N., and Clarke, R. K. (2008). Permanova+ for Primer: Guide to Software and Statistical Methods: Primer-E Limited, 1st Edn. Plymouth: PRIMER-E Ltd.

Anderson, M. J. (2001a). A new method for non-parametric multivariate analysis of variance. Austral. Ecol. 26, 32-46. doi: 10.1111/j.1442-9993.2001.0107 0.pp.x

\section{DATA AVAILABILITY STATEMENT}

This manuscript contains previously unpublished data. The name of the repository and accession number are not available.

\section{ETHICS STATEMENT}

The study present in the manuscript involve macrobenthos communities without endangered animal species.

\section{AUTHOR CONTRIBUTIONS}

$\mathrm{DZ}$ and RS conceived the study. LD wrote the manuscript. LD, LA, EB, RB, DZ, and RS provided samples from the field. EB and $\mathrm{RB}$ performed the samples pretreatment. EC provided chemical analysis. LD and RG provided taxonomic analysis. LD and LA performed statistical analysis. DZ, RS, and GR provided the sampling design and improved the manuscript. All the authors read, edited and approved the final manuscript.

\section{FUNDING}

Financial support was provided by the project "Prokaryotenematode Interaction in marine extreme envirONments: a uniquE source for ExploRation of innovative biomedical applications" (PIONEER) funded by the Total Foundation and IFREMER (2016-2019), and by the project Boost Europe ERC "Extreme marine nematoDes: moDel orgAnisms for a Journey toward the origin and Evolution of metazoan life in our changing planet" (EDDAJE) funded by the Brittany Region and IFREMER (2019).

\section{ACKNOWLEDGMENTS}

We are grateful to Soprintendenza of the Underwater Archeological Park of Baia (prot. 5667, 24/10/2016) for the authorization to sampling. We are thankful to Dr. Guido Villani for assistance during the underwater sampling and permission to use photos that enriched the manuscript. Thanks are also due to the diving center Centro SUB Pozzuoli (Guglielmo Fragale) for support field activities and Dr. Aurélie Tasiemski and Dr. Céline Boidin-Wichlacz for helping in sampling activities. We also thank the reviewers for the suggestions and comments. We are indebted to Dr. Jeroen Ingels (Florida State University) for useful discussions.

Anderson, M. J. (2001b). Permutation tests for univariate or multivariate analysis of variance and regression. Can. J. Fish. Aquat. Sci. 58, 626-639. doi: 10.1139/f01-004

Anderson, M. J. (2004). DISTLM v. 5: a FORTRAN Computer Program to Calculate a Distance-Based Multivariate Analysis for a Linear Model. Auckland: University of Auckland.

Anderson, M. J., and Willis, T. J. (2003). Canonical analysis of principal coordinates: a useful method of constrained ordination for ecology. 
Ecology 84, 511-525. doi: 10.1890/0012-9658(2003)084\%5B0511:caopca\%5D2. $0 . \mathrm{co} ; 2$

Arribas, L. P., Donnarumma, L., Palomo, M. G., and Scrosati, R. A. (2014). Intertidal mussels as ecosystem engineers: their associated invertebrate biodiversity under contrasting wave exposures. Mar. Biodivers. 44, 203-211. doi: $10.1007 / \mathrm{s} 12526-014-0201-\mathrm{z}$

Benson, B. L. (1989). Airlift sampler: applications for hard substrata. Bull. Mar. Sci. $44,752-756$

Bianchi, C. N., Dando, P. R., and Morri, C. (2011). Increased diversity of sessile epibenthos at subtidal hydrothermal vents: seven hypotheses based on observations at milos island Aegean Sea. Adv. Oceanogr. Limnol. 2, 1-31. doi: $10.1080 / 19475721.2011 .565804$

Blake, J. A. (2009). Redescription of capitella capitata (Fabricius) from west greenland and designation of a neotype (Polychaeta, Capitellidae). Zoosymposia 2, 55-80.

Bryan, G. W. (1976). Some Aspects of Heavy Metal Tolerance in Aquatic Organisms. Cambridge: Cambridge University Press.

Caldwell, R. S. (1975). Hydrogen Sulfide Effects on Selected Larval and Adult Marine Invertebrates. Corvallis, OR: Oregon State University.

Cardigos, F., Colaço, A., Dando, P. R., Ávila, S. P., Sarradin, P. M., Tempera, F., et al. (2005). Shallow water hydrothermal vent field fluids and communities of the D. João de Castro Seamount (Azores). Chem. Geol. 224, 153-168. doi: 10.1016/j.chemgeo.2005.07.019

Casoli, E., Bonifazi, A., Ardizzone, G., Gravina, M. F., Russo, G. F., Sandulli, R., et al. (2019). Comparative analysis of mollusc assemblages from different hard bottom habitats in the central tyrrhenian sea. Diversity 11:74. doi: 10.3390/ d11050074

Chemello, R., and Russo, G. F. (1997). The molluscan taxocoene of photophilic algae from the island of lampedusa (strait of sicily, southern mediterranean). Boll. Malacol. 33, 95-104.

Chianese, E., Trimberio, G., and Riccio, A. (2019). PM2.5 and PM10 in the urban area of naples: chemical composition, chemical properties and influence of air masses origin. J. Atmos. Chem. Inpress. 76, 151-169. doi: 10.1007/s10874-01909392-3

Cigliano, M., Gambi, M. C., Rodolfo-Metalpa, R., Patti, F. P., and Hall-Spencer, J. M. (2010). Effects of ocean acidification on invertebrate settlement at volcanic CO2 vents. Mar. Biol. 157, 2489-2502. doi: 10.1007/s00227-010-1513-6

Clarke, K. R., and Warwick, R. M. (2001). Change in Marine Communities an Approach to Statistical Analysis and Interpretation, 2nd Edn. Plymouth: Primer-E Ldt.

Colognola, R., Masturzo, P., Russo, G. F., Scardi, M., Vlnci, D., and Fresi, E. (1986). Biometric and genetic analysis of the marine rissoid rissoa auriscalpium (Gastropoda, Prosobranchia) and its ecological implications. Mar. Ecol. 7, 265-285. doi: 10.1111/j.1439-0485.1986.tb00163.x

Dando, P. R. (2010). "Biological communities at marine shallow-water vent and seep sites," in The Vent and Seep Biota, ed. S. Kiel, (Dordrecht: Springer), 333-378. doi: 10.1007/978-90-481-9572-5_11

Dando, P. R., Aliani, S., Arab, H., Bianchi, C. N., Brehmer, M., Cocito, S., et al. (2000). Hydrothermal studies in the aegean sea. Phys. Chem. Earth Part B Hydrol. Ocean. Atmos. 25, 1-8. doi: 10.1016/S1464-1909(99)00112-4

Dando, P. R., Hughes, J. A., and Thiermann, F. (1995). Preliminary observations on biological communities at shallow hydrothermal vents in the aegean Sea. Geol. Soc. London, Spec. Publ. 87, 303-317. doi: 10.1144/GSL.SP.1995.087. 01.23

Dando, P. R., Stüben, D., and Varnavas, S. P. (1999). Hydrothermalism in the mediterranean sea. Prog. Oceanogr. 44, 333-367. doi: 10.1016/S0079-6611(99) 00032-4

Desprez, M. (2000). Physical and biological impact of marine aggregate extraction along the french coast of the eastern english channel: short-and long-term postdredging restoration. ICES J. Mar. Sci. 57, 1428-1438. doi: 10.1006/jmsc.2000. 0926

Di Napoli, R., Aiuppa, A., Sulli, A., Caliro, S., Chiodini, G., Acocella, V., et al. (2016). Hydrothermal fluid venting in the offshore sector of Campi Flegrei caldera: a geochemical, geophysical, and volcanological study. Geochemistry. Geophys. Geosyst. 17, 4153-4178. doi: 10.1002/2016GC006494

Doney, S. C., Fabry, V. J., Feely, R. A., and Kleypas, J. A. (2009). Ocean acidification: the other CO2 problem. Ann. Rev. Mar. Sci. 1, 169-192. doi: 10.1146/annurev. marine.010908.163834
Donnarumma, L., Lombardi, C., Cocito, S., and Gambi, M. C. (2014). Settlement pattern of Posidonia oceanica epibionts along a gradient of ocean acidification: an approach with mimics. Mediterr. Mar. Sci. 15, 498-509. doi: 10.12681/mms. 677

Donnarumma, L., Sandulli, R., Appolloni, L., and Russo, G. F. (2018). Assessing molluscs functional diversity within different coastal habitats of marine protected areas. Ecol. Quest. 29, 35-51. doi: 10.12775/eq.2018.021

Dounas, C., and Koukouras, A. (1989). Sorne observations on the possible synonyrny of Eunice vittata (Delle Chiaje, 1825) and E. indica Kinberg, 1865 (Annelida, Polychaeta.). Cah. Biol. Mar. 30, 227-234.

Eleftheriou, A., and McIntyre, A. (eds) (2008). Methods for the Study of Marine Benthos, 3rd Edn. Hoboken, NJ: John Wiley \& Sons.

Ellingsen, K. E. (2002). Soft-sediment benthic biodiversity. Mar. Ecol. Prog. Ser. 232, 15-27. doi: 10.3354/meps232015

Fabry, V. J., Seibel, B. A., Feely, R. A., and Orr, J. C. (2008). Impacts of ocean acidification on marine fauna and ecosystem processes. ICES J. Mar. Sci. 65, 414-432. doi: 10.1093/icesjms/fsn048

Fauchald, K., Granados-Barba, A., and Solís-Weiss, V. (2009). "Polychaeta (Annelida) of the gulf of mexico," in Gulf of Mexico-Origins, Waters, and Biota. Biodiversity, eds D. L. Felder, and D. K. Camp, (College Station, TX: Texas A\&M University Press), 751-788.

Feder, H. M., Naidu, A. S., Jewett, S. C., Hameedi, J. M., Johnson, W. R., and Whitledge, T. E. (1994). The northeastern chukchi sea: benthos-environmental interactions. Mar. Ecol. Prog. Ser. 111, 171-190. doi: 10.3354/meps111171

Ferrero-Vicente, L. M., Marco-Méndez, C., Loya-Fernández, A., and SánchezLizaso, J. L. (2013). Limiting factors on the distribution of shell/tube-dwelling sipunculans. J. Exp. Mar. Bio. Ecol. 446, 345-354. doi: 10.1016/j.jembe.2013.06. 011

Fretter, V., and Graham, A. (1978). The prosobranch molluscs of britain and Denmark. Part 4 -Marine rissoacea. J. Molluscan Stud. suppl. 6, 153-241.

Gamenick, I., Abbiati, M., and Giere, O. (1998a). Field distribution and sulphide tolerance of Capitella capitata (Annelida: Polychaeta) around shallow water hydrothermal vents off milos (aegean sea). a new sibling species? Mar. Biol. 130, 447-453. doi: $10.1007 / \mathrm{s} 002270050265$

Gamenick, I., Vismann, B., Grieshaber, M. K., and Giere, O. (1998b). Ecophysiological differentiation of Capitella capitata (Polychaeta). Sibling species from different sulfidic habitats. Mar. Ecol. Prog. Ser. 175, 155-166. doi: 10.3354/meps175155

George, J. D., and Hartmann-Schröder, G. (1985). "Polychaetes: british amphinomida, spintherida and eunicida: keys and notes for the identification of the species," in Synopses of the British Fauna, eds M. Kermack, and R. S. K. Barnes, (London: Brill Archive), 1-221.

Grassle, J., and Grassle, J. F. (1976). Sibling species in the marine pollution indicator Capitella (Polychaeta). Science 192, 567-569. doi: 10.1126/science. 1257794

Gray, J. S., Wu, R. S. S., and Ying, Y. O. (2002). Effects of hypoxia and organic enrichment on the coastal marine environment. Mar. Ecol. Prog. Ser. 238, 249-279. doi: 10.3354/meps 238249

Gusso, C. C., Gravina, M. F., and Maggiore, F. R. (2001). Temporal variations in soft bottom benthic communities in central tyrrhenian sea (Italy). Archo. Ocean. Limnol. 22, 175-182.

Hall-Spencer, J. M., Rodolfo-Metalpa, R., Martin, S., Ransome, E., Fine, M., Turner, S. M., et al. (2008). Volcanic carbon dioxide vents show ecosystem effects of ocean acidification. Nature 454:96. doi: 10.1038/nature07051

Legendre, P., and Anderson, M. J. (1999). Distance-based redundancy analysis: testing multispecies responses in multicfacorial ecological experiments. Ecol. Monogr. 69, 1-24. doi: 10.1890/0012-9615(1999)069\%5B0001:dbratm\%5D2.0. $\mathrm{co} ; 2$

Lloret, J., and Marín, A. (2009). The role of benthic macrophytes and their associated macroinvertebrate community in coastal lagoon resistance to eutrophication. Mar. Poll. Bull. 58, 1827-1834. doi: 10.1016/j.marpolbul.2009. 08.001

Lucey, N. M., Lombardi, C., Florio, M., DeMarchi, L., Nannini, M., Rundle, S., et al. (2016). An in situ assessment of local adaptation in a calcifying polychaete from a shallow CO2 vent system. Evol. Appl. 9, 1054-1071. doi: 10.1111/eva.12400

Lutz, R. A., and Kennish, M. J. (1993). Ecology of deep-sea hydrothermal vent communities: a review. Rev. Geophys. 31, 211-242.

Martin, W., Baross, J., Kelley, D., and Russell, M. J. (2008). Hydrothermal vents and the origin of life. Nat. Rev. Microbiol. 6, 805-814. doi: 10.1038/nrmicro1991 
Maugeri, T. L., Bianconi, G., Canganella, F., Danovaro, R., Gugliandolo, C., Italiano, F., et al. (2010). Shallow hydrothermal vents in the southern tyrrhenian sea. Chem. Ecol. 26, 285-298. doi: 10.1080/0275754100369 3250

Micheli, F., Peterson, C. H., Mullineaux, L. S., Fisher, C. R., Mills, S. W., Sancho, G., et al. (2002). Predation structures communities at deep-sea hydrothermal vents. Ecol. Monogr. 72, 365-382. doi: 10.1111/1462-2920.14806

Nygren, A. (2014). Cryptic polychaete diversity: a review. Zool. Scr. 43, 172-183. doi: $10.1111 /$ zsc. 12044

Parson, L. M., Walker, C. L., and Dixon, D. R. (1995). Hydrothermal vents and processes. Geol. Soc. Spec. Publ. 87, 1-2.

Passaro, S., Barra, M., Saggiomo, R., Di Giacomo, S., Leotta, A., Uhlen, H., et al. (2013). Multi-resolution morpho-bathymetric survey results at the PozzuoliBaia underwater archaeological site (Naples. Italy). J. Archaeol. Sci. 40, 12681278. doi: 10.1016/j.jas.2012.09.035

Purchon, R. D. (1977). The Biology of the Mollusca, 2nd Edn. Amsterdam: Elsevier.

Raghukumar, C., Mohandass, C., Cardigos, F., DeCosta, P. M., Santos, R. S., and Colaco, A. (2008). Assemblage of benthic diatoms and culturable heterotrophs in shallow-water hydrothermal vent of the D. Joao de Castro seamount, azores in the atlantic ocean. Curr. Sci. 95, 1715-1723.

Riera, R., Monterroso, Ó, and Núñez, J. (2012). Effects of granulometric gradient on macrofaunal assemblages in Los Cristianos harbour (tenerife, canary islands). arquipélago. Life Mar. Sci. 29, 33-41.

Rota, E., Perra, G., and Focardi, S. (2009). The European lancelet Branchiostoma lanceolatum (Pallas) as an indicator of environmental quality of tuscan archipelago (western mediterranean sea). Chem. Ecol. 25, 61-69. doi: 10.1080/ 02757540802641361

Schander, C., Rapp, H. T., Kongsrud, J. A., Bakken, T., Berge, J., Cochrane, S., et al. (2010). The fauna of hydrothermal vents on the mohn ridge (North Atlantic). Mar. Biol. Res. 6, 155-171. doi: 10.1080/17451000903147450

Schumacher, B. A. (2002). Methods for the Determination of Total Organic Carbon (TOC) in Soils and Sediments. Washington, DC: United States Environmental Protection Agency, National ESD (Exposure Research Laboratory).

Simboura, N., and Zenetos, A. (2002). Benthic indicators to use in ecological quality classification of mediterranean soft bottom ecosystems, including a new biotic index. Mediterr. Mar. Sci. 3, 77-112.

Southward, A. J., Southward, E. C., Dando, P. R., Hughes, J. A., Kennicutt, M. C., Herrera-Alcala, J., et al. (1997). Behaviour and feeding of the nassariid gastropod cyclope neritea, abundant at hydrothermal brine seeps off milos (aegean sea). J. Mar. Biol. Assoc. U.K. 77, 753-771. doi: 10.1017/ s0025315400036171

Stevens, C. J., Juniper, S. K., Limén, H., Pond, D. W., Metaxas, A., and Gélinas, Y. (2015). Obligate hydrothermal vent fauna at East Diamante submarine volcano (mariana arc) exploit photosynthetic and chemosynthetic carbon sources. Mar. Ecol. Prog. Ser. 525, 25-39. doi: 10.3354/meps11229

Tarasov, V. G., Gebruk, A. V., Mironov, A. N., and Moskalev, L. I. (2005). Deep-sea and shallow-water hydrothermal vent communities: two different phenomena? Chem. Geol. 224, 5-39. doi: 10.1016/j.chemgeo.2005.07.021

Tarasov, V. G., Gebruk, A. V., Shulkin, V. M., Kamenev, G. M., Fadeev, V. I., Kosmynin, V. N., et al. (1999). Effect of shallow-water hydrothermal venting on the biota of matupi harbour (Rabaul Caldera, New Britain Island, Papua New Guinea). Cont. Shelf Res. 19, 79-116. doi: 10.1016/S0278-4343(98) 00073-9

Tedesco, D., Allard, P., Sano, Y., Wakita, H., and Pece, R. (1990). Helium3 in subaerial and submarine fumaroles of Campi Flegrei caldera, Italy. Geochim. Cosmochim. Acta 54, 1105-1116. doi: 10.1016/0016-7037(90) 90442-N

Teixidó, N., Gambi, M. C., Parravacini, V., Kroeker, K., Micheli, F., Villéger, S., et al. (2018). Functional biodiversity loss along natural CO2 gradients. Nat. Commun. 9:5149. doi: 10.1038/s41467-018-07592-1

Terlizzi, A., Anderson, M. J., Fraschetti, S., and Benedetti-Cecchi, L. (2007). Scales of spatial variation in Mediterranean subtidal sessile assemblages at different depths. Mar. Ecol. Prog. Ser. 332, 25-39. doi: 10.3354/meps33 2025

Thiermann, F., Akoumianaki, I., Hughes, J. A., and Giere, O. (1997). Benthic fauna of a shallow-water gaseohydrothermal vent area in the aegean sea (Milos, Greece). Mar. Biol. 128, 149-159. doi: 10.1007/s002270050078

Thrush, S. F., Pridmore, R. D., Hewitt, J. E., and Cummings, V. J. (1991). Impact of ray feeding disturbances on sandflat macrobenthos: do communities dominated by polychaetes or shellfish respond differently? Mar. Ecol. Prog. Ser. 69, 245252. doi: 10.3354/meps069245

Turner, L. M., Ricevuto, E., Massa Gallucci, A., Lorenti, M., Gambi, M. C., and Calosi, P. (2016). Metabolic responses to high pCO2 conditions at a CO2 vent site in juveniles of a marine isopod species assemblage. Mar. Biol. 163:211. doi: 10.1007/s00227-016-2984-x

Underwood, A. J. (1997). Experiments in Ecology: Their Logical Design and Interpretation Using Analysis of Variance. Cambridge: Cambridge University Press.

Van Dover, C. L., and Fry, B. (1989). Stable isotopic compositions of hydrothermal vent organisms. Mar. Biol. 102, 257-263. doi: 10.1007/BF00428287

Vaquer-Sunyer, R., and Duarte, C. M. (2010). Sulfide exposure accelerates hypoxiadriven mortality. Limnol. Oceanogr. 55, 1075-1082. doi: 10.4319/1o.2010.55.3. 1075

Vaquer-Sunyer, R., and Duarte, C. M. (2011). Temperature effects on thresholds of hypoxia for marine organisms. Glob. Chang. Biol. 17, 1788-1797. doi: 10.1007/ s11356-017-8908-6

Vismann, B. (1991). Sulfide tolerance: physiological mechanisms and ecological implications. Ophelia 34, 1-27. doi: 10.1080/00785326.1991.10429703

Wang, F., and Chapman, P. M. (1999). Biological implications of sulfide in sediment - a review focusing on sediment toxicity. Environ. Toxicol. Chem. 18, 2526-2532. doi: 10.1002/etc.5620181120

Washburn, T., Rhodes, A. C. E., and Montagna, P. A. (2016). Benthic taxa as potential indicators of a deep-sea oil spill. Ecol. Indic. 71, 587-597. doi: 10.1016/ j.ecolind.2016.07.045

Wicks, L. C., and Roberts, M. J. (2012). "Benthic invertebrates in a high-CO2 world," in Oceanography and Marine Biology - An Annual Review, eds R. N. Gibson, R. J. A. Atkinson, J. D. M. Gordon, and R. N. Hughes, (Milton Park: Taylor \& Francis), 127-188.

Woodin, S. A. N. N. (1978). Refuges, disturbance, and community structure: a marine soft-bottom example. Ecology 59, 274-284.

WoRMS Editorial Board, (2018). World Register of Marine Species. Available at: http://www.marinespecies.org at VLIZ (accessed June 19, 2018).

Yao, H., Dao, M., Imholt, T., Huang, J., Wheeler, K., Bonilla, A., et al. (2010). Protection mechanisms of the iron-plated armor of a deep-sea hydrothermal vent gastropod. Proc. Natl. Acad. Sci. U.S.A. 107, 987-992. doi: 10.1073/pnas. 0912988107

Yoshida, M., Hamdi, H., Abdul Nasser, I., and Jedidi, N. (2002). Contamination of potentially toxic elements (PTEs) in bizerte lagoon bottom sediments, surface sediment and sediment repository. Rpp Sepmcl. 13-48.

Zhao, Q., Cheung, S. G., Shin, P. K. S., and Chiu, J. M. Y. (2011). Effects of starvation on the physiology and foraging behaviour of two subtidal nassariid scavengers. J. Exp. Mar. Bio. Ecol. 409, 53-61. doi: 10.1016/j.jembe.2011.08.003

Conflict of Interest: The authors declare that the research was conducted in the absence of any commercial or financial relationships that could be construed as a potential conflict of interest.

Copyright (c) 2019 Donnarumma, Appolloni, Chianese, Bruno, Baldrighi, Guglielmo, Russo, Zeppilli and Sandulli. This is an open-access article distributed under the terms of the Creative Commons Attribution License (CC BY). The use, distribution or reproduction in other forums is permitted, provided the original author(s) and the copyright owner(s) are credited and that the original publication in this journal is cited, in accordance with accepted academic practice. No use, distribution or reproduction is permitted which does not comply with these terms. 